\title{
Myxomycetes of the Taimyr Peninsula (north-central Siberia)
}

\author{
YURI K. NOVOZHILOV, MARTIN SCHNITTLER and STEVENL. STEPHENSON
}

NOVOZHILOV, Y. K., SCHNITTLER, M. \& STEPHENSON, S. L. 1999: Myxomycetes of the Taimyr Peninsula (north-central Siberia). - Karstenia 39:77-97. Helsinki. ISSN 0435-3402

\begin{abstract}
Fifty-six species of myxomycetes representing 26 genera were identified from 371 collections that originated almost exclusively from 270 moist chamber cultures prepared with samples of decaying plant material collected on the Taimyr Peninsula (Russia, north-central Siberia) and in the adjacent Putorana Plateau. Species numbers decrease progressively from northern taiga and forest-tundra over southern tundra to the typical tundra subzone. Forty species in 18 genera were recorded in the northern taiga subzone, 40 species in 19 genera in forest-tundra, and 25 species in 17 genera in the tundra subzones. A taxonomic specificity or community endemism of myxomycete assemblages in tundra as compared to those of northern taiga communities was not found. In general, the myxomycete biota of the tundra zone of the Taimyr Peninsula can be considered as an impoverished biota of the northern taiga subzone. Ten ubiquitous species were recorded from at least one half of all studied localities. The average number of species per genus (2.1) calculated in our study indicates a rather low species diversity for high latitudes, contrary to the biotas of temperate and tropical zones where this ratio ranges from 2.2 to 4.6. Values for coefficient of community, calculated for all pairwise combinations of different study areas in the Arctic, ranged from 0.45 to 0.63 , thus indicating fairly high levels of similarity among arctic and subarctic myxomycete biotas.
\end{abstract}

Key words: myxomycetes, biodiversity, ecology, Arctic, Russia, Taimyr Peninsula

Yuri K. Novozhilov, V.L. Komarov Botanical Institute of the Russian Academy of Sciences, Prof. Popov Str. 2, 197376 St. Petersburg, Russia

Martin Schnittler, Steven L. Stephenson, Fairmont State College, Fairmont, West Virginia 26554-2470, U.S.A.

\section{Introduction}

Myxomycetes (plasmodial slime moulds) are common inhabitants of decaying plant material in boreal forests of the taiga zone, as shown by several studies in Alaska (Stephenson \& Laursen 1990, 1998), Scandinavia (Eliasson \& Strid 1976; Härkönen 1978, 1979a, b; Johannesen 1984; Schinner 1983), and north-western Russia (Novozhilov 1985; Schnittler \& Novozhilov 1996). Probably some species common in the taiga can move farther north to the zone of foresttundra and tundra, invading new and unusual microhabitats. At present, myxomycete communities of open forest-tundra, tundra, and herb- rich grassland ecosystems of high-latitude regions of the Arctic and Subarctic have received relatively little study (Ing 1994). Major surveys have been carried out in certain regions of the Subarctic and Arctic, including Iceland (Gøtzsche 1984, 1990), Greenland (Gøtzsche 1989), Alaska (Stephenson \& Laursen 1990, 1993, 1998; Stephenson et al. 1994), and the northern biological province Inarin Lappi in Finland (Härkönen 1979b). Available information for the myxomycetes of the Russian Arctic is fragmentary and rather meagre (Novozhilov et al. 1998a, b). Only a few papers with species lists for some 
areas such as the Khibine Mountains in the Kola Peninsula (Novozhilov \& Schnittler 1997), the Chukchi Peninsula (Novozhilov 1986, Stephenson et al. 1994), and the Taimyr Peninsula (Novozhilov \& Schnittler 1996) have been published previously. The primary objective of the research reported herein was to obtain data on the distribution and ecology of myxomycetes in tundra, forest-tundra, and northern taiga forest ecosystems of the Taimyr Peninsula of northcentral Siberia and adjacent areas of the Putorana Plateau.

\section{Materials and methods}

The main sources of information used in the present study were specimens obtained from moist chamber cultures of various substrata, especially those on which corticolous and fimicolous species of myxomycetes are known to occur, and to a lesser extent field collections of myxomycetes. For each vegetation unit, an effort was made to examine all types of microhabitats upon which sporocarps of myxomycetes might be expected. These included the bark surface of living trees and shrubs, litter of shrubs and trees as well as from various herbaceous plants, and the dung of herbivorous animals. Two hundred and seventy moist chamber cultures were prepared as described by Härkönen (1977, 1981a) and Stephenson $(1985,1989)$ and maintained for up to 2.5 months. Herein, a 'collection' is defined as one or more fruiting bodies considered to have originated from a single plasmodium (Stephenson 1989). In virtually all cases, this could be determined without difficulty. For moist chamber cultures, the occurrence of one species in one Petri dish was considered as one collection. For each moist chamber, $\mathrm{pH}$ values were determined using an Orion model $610 \mathrm{pH}$ meter.

Myxomycete communities were compared using the Sorenson - Czekanowski coefficient of community (Roberts 1986). This index ranges from 0 (no species in common) to 1 (all species are members of both communities). Species diversity indices were calculated using Shannon's formula (Shannon \& Weaver 1963). Species diversity $\left(\mathrm{H}^{\prime}\right)=-\Sigma \mathrm{P}_{\mathrm{i}} \log \mathrm{P}_{\mathrm{i}}$, where $\mathrm{P}_{\mathrm{i}}$ is the relative abundance of a particular species (the proportion of the total number of individuals represented by species i). Maximum values for this diversity index are usually observed when there are many species with equal abundances. Values decrease with both a reduction in the number of species and an increase in abundance of a very few species.

Nomenclature used herein follows Martin \& Alexopoulos (1969) for myxomycetes, with a few exceptions indicated by taxonomic references, and Czerepanov (1995) for vascular plants. For determination, sporocarps were often preserved as permanent slides in polyvinyl lactophenol and/or glycerol gelatine, to distinguish between limeless and lime-containing structures. Colour descriptions in taxonomical comments are given according to Petersen (1996). In several cases, sporocarp structures were studied with a JEOL 35c scanning electron microscope (SEM) at St. Petersburg. Specimens are deposited in the Komarov Botanical Institute of the Russian Academy of Sciences, Laboratory of Systematics and Geography of Fungi (LE), as well as in the private collection of the second author, which is stored at the herbarium Haussknecht, Jena, Germany (JE).

\section{Study area}

The Taimyr Peninsula and the adjacent Putorana Plateau are some of the harshest landscapes of north-central Siberia. The highly continental climate is characterised by winter temperatures that drop as low as $-45^{\circ} \mathrm{C}$. Average January and July temperatures are $-30.6^{\circ}$ and $+11.4^{\circ} \mathrm{C}$, respectively. In summer, the temperature rises rapidly, exceeding $+10^{\circ} \mathrm{C}$ at the end of June. Maximum air temperatures in July can be very high in the tundra and may reach $20{ }^{\circ} \mathrm{C}$. The annual precipitation in the region ranges between 300 and $350 \mathrm{~mm}$, with approximately one-third falling as rain in July-August (Chernov \& Matveyeva 1997; Romanova 1971).

Study sites included all typical plant communities in the tundra, forest-tundra and northern taiga. These three vegetation zones intergrade frequently within relatively small distances, often resulting in a vegetation mosaic. Therefore, an exact geographical delimitation is almost impossible (Alexandrova 1977, Kozhevnikov 1996, Sirois 1983, Tikhomirov 1970). On the Taimyr Peninsula, the tundra belt extends $600-700 \mathrm{~km}$ from south to north, with a southern border at about $72{ }^{\circ} \mathrm{N}$ (Fig. 1). In the south, it borders the forest-tundra and in the north the polar desert (Fig. 2). As an ecotone, the forest-tundra zone connects the two contrasting types of landscape (Chernov \& Matveyeva 1997).

Myxomycete and substratum samples were collected from mid-June to mid-July during the

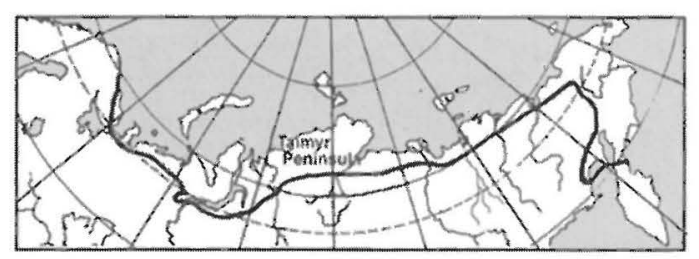

Fig 1. Geographical location of the Taimyr Peninsula within Russia. A solid line indicates the northern limit of boreal forests according to Tolmachev (1960).

1995-96 field seasons at 10 localities (Figs. 1, 2). These are listed below.

1. Putorana Plateau, slopes of hills called "Krasnyi Kamen"', ca. $80 \mathrm{~km} \mathrm{~N}$ of the city of

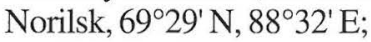

2. Taimyr Peninsula, Kayak settlement, the watershed of the Kotuy River, $71^{\circ} 30^{\prime} \mathrm{N}, 103^{\circ} 00^{\prime} \mathrm{E}$;

3. Kheta settlement, the watershed of the Kheta River, $71^{\circ} 31^{\prime} \mathrm{N}, 99^{\circ} 24^{\prime} \mathrm{E}$; 
4. Khatanga city, the shore of the Kazach'ia River, $72^{\circ} 00^{\prime} \mathrm{N}, 102^{\circ} 38^{\prime} \mathrm{E}$;

5. Zhdanikha settlement, the watershed of the Khatanga River, the Nuzhdina Gulf, $72^{\circ} 17^{\prime}$ $\mathrm{N}, 103^{\circ} 22^{\prime} \mathrm{E}$;

6. Pekas-Khory Island, the watershed of the Khatanga River, $72^{\circ} 27^{\prime} \mathrm{N}, 103^{\circ} 30^{\prime} \mathrm{E}$;

7. The watershed of the Khatanga River on the Oboynaya Gulf, $72^{\circ} 28^{\prime} \mathrm{N}, 104^{\circ} 15^{\prime} \mathrm{E}$;

8. Starorybnoe settlement on the northern bank of the Khatanga River, $72^{\circ} 45^{\prime} \mathrm{N}$, $104^{\circ} 50^{\prime} \mathrm{E}$;

9. Severnyi Promontory in the region of the watershed of the Khatanga River, $72^{\circ} 46^{\prime} \mathrm{N}$, $105^{\circ} 14^{\prime} \mathrm{E}$;

10. The Kosmatyi Promontory on the watershed of the Khatanga River, $73^{\circ} 39^{\prime} \mathrm{N}, 109^{\circ} 42^{\prime} \mathrm{E}$.
Elevations of study sites on the Putorana Plateau (loc.1) vary between 100 and $200 \mathrm{~m}$ above sea level, resulting in the presence of all vegetation zones from northern taiga to montane polar desert (Kozhevnikov 1996). The Taimyr Peninsula is a lowland and all investigated localities (2-10) are located at elevations below $50 \mathrm{~m}$. A transect, extending from northern taiga on the Kotui River (loc. 2) and on the Kheta River (3) to forest-tundra (4-7), southern tundra (6-8), and typical tundra (9-10) in the watershed of the Khatanga River was studied.

Five vegetation subzones were differentiated and consecutively numbered by Roman numerals (Fig. 2):

I. Northern taiga (loc. 1-3). The timberline (boundary of zonal woodlands) delimiting this subzone northwards is formed mainly by pure larch (Larix gmelinii) forests. As considered herein, northern taiga is regarded as light, open-

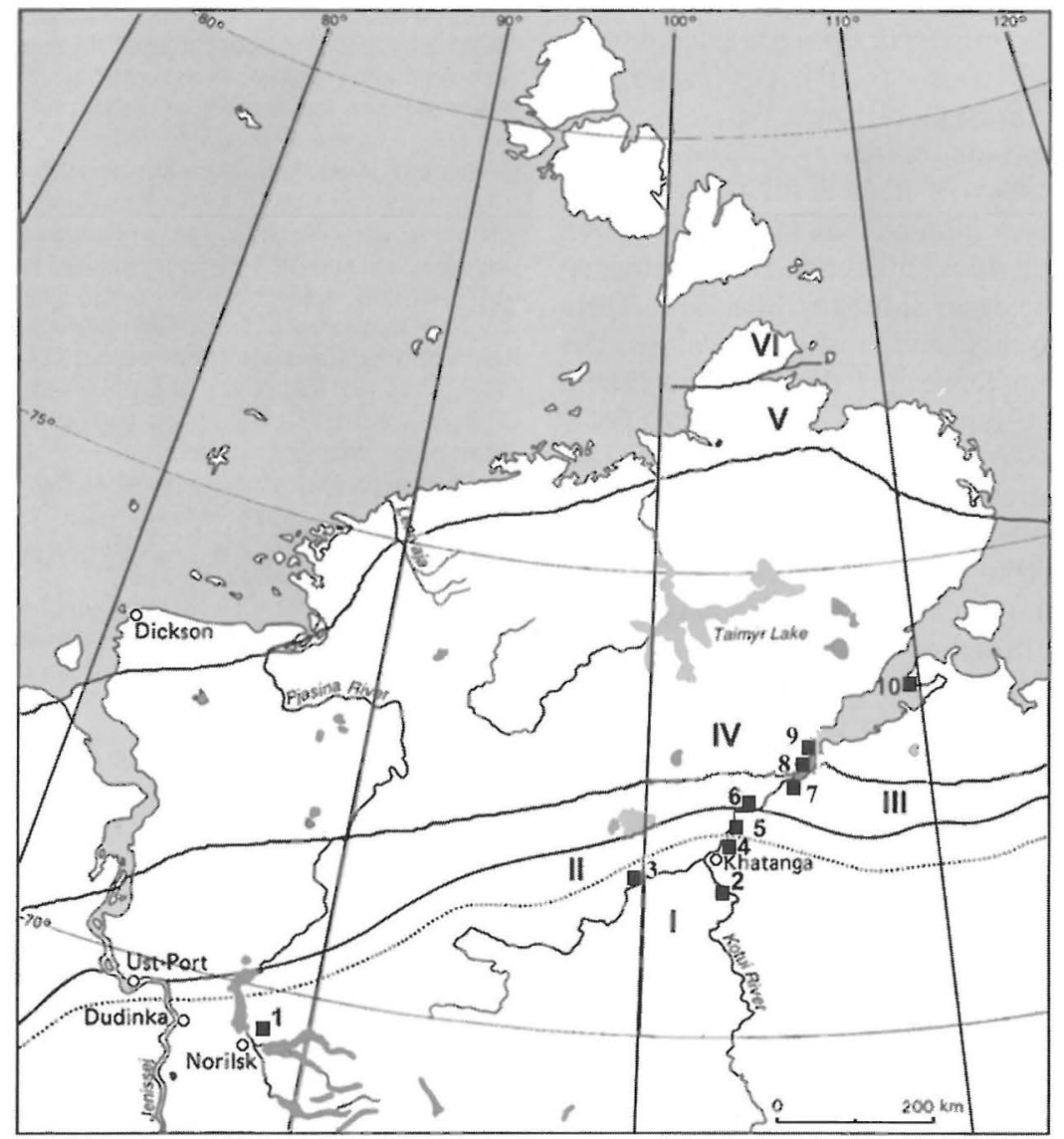

Fig. 2. Map of the Taimyr Peninsula showing the location of the ten study sites (black rectangles). Numbers refer to the sites listed in the text. A dotted line shows the northern boundary of the light larch taiga, whereas solid black lines indicate the boundaries of the tundra subzones: I - northern taiga; II - forest-tundra; III - southern tundra; IV typical tundra; V - arctic tundra; VI - polar desert. Map compiled from Chernov \& Matveyeva (1997). 
crowned forest with $<60 \%$ canopy coverage. Fallen trees are mainly exposed to direct sunlight, which slows down their decay, thus probably excluding some wood-inhabiting myxomycetes. In the Putorana Plateau, spruce (Picea obovata) is intermixed in the larch stands. On wet depressions, rich herbfields of tall perennials such as Cirsium helenioides or Heracleum sibiricum can be found in the understorey.

II. Forest tundra (loc. 1, 3, 4, 5). Here, closed larch woodlands appear only locally under favourable conditions (e.g., in stream valleys or on south-facing slopes), with small, widely separated trees up to $10 \mathrm{~m}$ in height. Logs up to $40 \mathrm{~cm}$ thickness may occur. To the north, but also in the natural meadows of the stream valleys, shrub thickets (Duschekia fruticosa and Salix spp.) intermixed with single, small larch trees dominate. In the Putorana Plateau, tall and large thickets of willows, alder (Duschekia fruticosa), and juniper (Juniperus communis ssp. sibirica) form a subalpine forest-tundra on hillsites.

III. Southern tundra (loc. 6-8). The absolute northern boundary of trees delimits the tundra. As used here, "tundra" includes vegetation types that range from tall shrub communities up to $1.5 \mathrm{~m}$ high to dwarf shrub heathlands $(5-20 \mathrm{~cm}$ high) and graminoid and moss communities. The most important feature of the southern tundra subzone is the presence of shrubs (Duschekia fruticosa and Salix spp.) growing up to $1.5 \mathrm{~m}$ tall. These tall and closed shrub thickets are typical for "intrazonal" biotopes, such as river valleys, rivulets, and lake depressions and can provide medium-sized pieces of coarse woody debris..

IV. Typical tundra (loc. 9, 10). Low shrubs such as dwarf birch (Betula nana), up to $50 \mathrm{~cm}$, and various dwarf willows prevail in the typical tundra. On the ground beneath these very dense thickets, leafy litter accumulates, sheltered from the strong winds. Coarse woody debris is still present, usually as twigs $1-3 \mathrm{~cm}$ (rarely up to 10 $\mathrm{cm}$ ) in diameter.

V. Arctic tundra (locality 1 ). This subzone was investigated as mountain tundra in the Putorana Plateau only. At elevations greater than $200 \mathrm{~m}$, arctic mountain tundra with dwarf birch and various prostate ericaceous shrubs prevails. Locally, shrub thickets $>-10 \mathrm{~cm}$ in height occur, but grass- or lichen-rich communities dominate. Small accumulations of litter still exist, and coarse woody debris can be found as small twigs and trunks mostly $<2 \mathrm{~cm}$ diameter. Wind-exposed sites are already free of vegetation.

VI. Polar desert (not investigated). In this subzone, mosses and lichens dominate, and shrubs grow only with subterranean twigs (e.g. Salix polaris). The limited vegetation present forms no closed cover.

\section{Annotated species list}

The following annotated list includes all recorded species in alphabetical order. Species names are followed by the collection numbers of the first author (numbers of five or six digits) and/or the second author (numbers of four digits). The string "..." indicates common species for which not all collection numbers were listed. Determinations considered as doubtful are given with the note "cf." (confer). The total numbers of records for field and moist chamber collections (symbols "fc" and "mc") are provided in brackets, followed by the locality numbers as given in Fig. 2, with the number of records for each locality given in parentheses. Next, the distribution of species in different vegetation subzones and microhabitats is listed. The vegetation subzone is indicated by a Roman numeral. After a colon, the number of records is given, separated by a hyphen from the abbreviation of the name of the plants providing the substratum. Substratum types (listed in parentheses) were classified as following: w-decayed coarse woody debris ( $>10 \mathrm{~cm}$ in diameter); b-bark of living trees and shrubs; 1-litter, including leaves, branchlets, or Duschekia catkins as well as remnants of various herbaceous plants; and d-dung of herbivorous animals, such as the lemming (Lemmus lemmus), hare (Lepus sp.), reindeer (Rangifer tarandus), and polar partridge (Lagopus lagopus). All collections upon bark and litter originated from moist chamber cultures.

Plant names were abbreviated as Bet. - Betula nana, Dus. - Duschekia fruticosa, Lar. - Larix gmelinii, Jun. Juniperus communis, Pic. - Picea obovata, Sal. - Salix spp., and Sor - Sorbus aucuparia.

For an estimation of species abundance, the percentage scale of Stephenson et al. (1993) was adapted. This is based upon the proportion of a species to the total number of records: R-rare $(<0.5 \%$, recorded once or twice), O-occasional ( $>0.5-1.5 \%, 3-6$ records), Ccommon ( $>1.5-3 \%, 7-11$ records), $\mathrm{A}-$ abundant $(>3 \%$, more than 11 records). Since our field survey took place in June, many species of xylophilous myxomycetes that sporulate later in the year may be underrepresented. Consequently, this scale was applied to moist chamber collections only.

In the list, abbreviations used for the distribution of myxomycetes in subarctic and arctic regions were IC Iceland (Gøtzsche 1984, 1990), FL - northern biological province Inarin Lappi in Finland (Härkönen 1979b), KP - Kola Peninsula (Novozhilov \& Schnittler 1997), PU - Polar Ural, YP - Yamal Peninsula (Novozhilov et al. 1998a), CP - northern-eastern part of the Chukchi Peninsula (Novozhilov 1986, Stephenson et al. 1994), AL - Alaska (Stephenson \& Laursen 1990, 1993, 1998; Stephenson et al. 1994), and GR - Greenland (Gøtzsche 1989). 
A Arcyria cinerea (Bull.) Pers. 48959...; [fc - 1; mc-42]. Loc. 1 (20), 2 (9), 4 (1), 5 (7), 6(1), 7 (5). I: 2 -Dus. (w), 4 -Lar. (w), 2 -Pic. (w), 1 -Sal. (w), 2 -Jun. (b), 1 - Pic. (b), 2 - Sal. (b), 1 - Dus. (1). III: 1 -Dus. (w), 5 - Lar. (w), 1-Dus. (b), 1 - Sal. (b), 3 -Dus. (1). IIII: 5 -Dus. (w), 1-Lar. (w), 1-Dus. (b), 1 - Sal. (b), 3 -Jun. (b), 2 -Dus. (1), 2 - hare (d). V: 2 -Sal. (b). Appearing regularly in moist chamber cultures of decaying wood but also inhabiting bark of living trees and shrubs, rarely occurring on litter and dung. One of the most common and abundant myxomycetes in the Taimyr Peninsula, recorded also from numerous localities in the Subarctic and Arctic. - IC, FL, KP, PU, YP, CP, AL, GR.

R Arcyria denudata (L.) Wettst. 49161, 49229; [mc-2]. Loc. 1 (1), 2(1). I: 1 - Pic. (w), 1-Lar. (w). Widely distributed in boreal forests but seemingly less common than the previous species in the Arctic. On the Taimyr Peninsula recorded from the northern taiga zone only, also collected from Inarin Lappi (Finland). As a typically wood-inhabiting species, it is clearly underrepresented in our study.

A Arcyria incarnata (Pers.) Pers. 48964...; [fc -1; mc-14]. Loc. 1(6), 2 (7), 5 (1), 6 (1). I: 2 - Pic. (w), 4 - Lar. (w), 2 - Sal. (w), 1 - Sal. (b). III: 3 Lar: (w). IIII: 3 - Dus. (w). - IC, FL, PU, CP, AL, GR.

R Arcyria obvelata (Oeder) Onsberg 48970, 49242; [fc-1, mc-1]. Loc. 1 (2). I: 2 -Pic. (w). Apparently rare in the Subarctic and Arctic (FL, $\mathrm{KP}$ ), as a wood-inhabiting species probably underrepresented in this survey.

O Arcyria pomiformis (Leers) Rostaf. 49136...; [mc-3]. Loc. 1 (1), 2 (1), 4(1). I: 2 - Lar. (w). III: 1 Lar. (w). - FL, KP, CP, AL, GR.

R Arcyodes incarnata (Alb. \& Schwein.) O.F. Cook 49179 [mc]. Loc. 2. II: 1 - Sal. (w). - KP, CP.

R Calomyxa metallica (Berk.) Nieuwl. 7131; [mc-1]. Loc. 2 (1). I: 1 - Lar. (w). - IC, PU, YP, CP, AL, GR.

O Ceratiomyxa fruticulosa (O.F. Müll.) T. Macbr. $48965 \ldots$; [fc - 3, mc - 3]. Loc. 1 (5), 2 (1). I: 1 Dus. (w), 2 -Pic. (w), 1 - Lar. (w). III: 1 -Lar. (w). IIII: 1 -Dus. (w). Seemingly restricted to coarse woody debris, whose availability limits its distribution northwards. - IC, FL, KP, PU, CP, AL, GR.

R Comatricha laxa Rostaf. 49182; [mc]. Loc. 1. I: 1 - Pic. (w). Probably common in the boreal zone (Schnittler \& Novozhilov 1996) but rare in the Arctic. - IC, PU, CP, AL, GR.

A Comatricha nigra (Pers.) J. Schröt. 48919...; [fc $-5, \mathrm{mc}-42]$. Loc. 1 (11), 2 (14), 4 (2), 5 (10), 6 (1), 7 (9). I: 2 -Dus. (w), 2-Lar. (w), 1 -Pic. (w), 1 -Sal. (w), 7 -Lar. (b), 3 - Pic. (b). II: 1 -Dus. (w), 3-Lar. (w), 1-Sal. (w), 14-Lar. (b), 1-Dus. (l). IIII: 3 - Dus. (w), 1 - Lar. (w), 6 - Lar. (b), 1 Dus. (b). Common in the Arctic in all typical plant communities in the tundra, forest-tundra, and northern taiga. - IC, FL, KP, PU, CP, AL, GR.

$\mathrm{R}$ Comatricha pulchella (C. Bab.) Rostaf. 7375; [mc]. Loc. 2 (1). I: 1 - Lar. (w). Apparently rare in the Arctic.

$\mathrm{R}$ Craterium leucocephalum (Pers.) Ditmar 204185; [mc]. Loc. 9 (1). IV: Sal. (w). One record on small Salix twigs from the litter layer. Probably a species requiring relatively high temperatures for development and therefore rare in the Arctic. - IC, PU, AL.

R Cribraria cf. atrofusca G.W. Martin et Lovejoy 49237; [mc]. Loc. 2 (1). I: Lar. (w). In the Arctic, so far known only from the Taimyr Peninsula.

With its long stalks and small capitula, this form approaches $C$. languescens in habit. Deviating characters are the large spores (9.6-)10.2$11.4(-13.2) \mu \mathrm{m}$ in diameter and the strongly thickened, pillow-shaped nodes of the peridial network.

O Cribraria microcarpa (Schrad.) Pers. 7112, 7211, 7216, 7327; [mc-4]. Loc. 2 (2), 4 (1), 5 (1). I: 2 - Lar. (w). III: 2 - Lar. (w). In the Arctic known only from the Taimyr Peninsula. A widely distributed species often occurring in moist chambers. In the present survey found on decorticated, large Larix logs.

O Cribraria violacea Rex 49156, 49199, 49241, 7342; [mc-4]. Loc. 2 (4). I: 1 - Lar. (w), 1 - Sal. (w). 1 - Sal. (b). II: 1 - Sal. (b). A mostly tropical species with probably higher temperature requirements than provided by typical conditions in the Arctic. Our records and additional ones from Alaska, both arctic regions with a continental climate and comparatively high summer temperatures, seem to confirm this.

R Cribraria vulgaris Schrad. 49157; [mc]. Loc. 2. III: 1 - Lar. (w). Widely distributed within the temperate zone but very rare in the Arctic, where it is known only from the Taimyr Peninsula.

- Diderma radiatum (L.) Morgan 48944; [fc]. Loc. 5. II: 1 - Lar. (w). - FL, CP, AL.

R Didymium difforme (Pers.) S.F.Gray 49109; [mc]. Loc. 5. II: 1 - polar partridge (d). In contrast to other coprophilous species $D$. difforme can 
utilise acidic dung (in our case a $\mathrm{pH}$ of 5.9 was measured). Widely distributed over all continents and also common in the Arctic, where appears on litter and the dung of herbivorous animals (Eliasson \& Keller 1999; Eliasson \& Lundqvist 1979). Also common on cultivated grain (Härkönen \& Koponen 1978). - KP, YP, CP, AL, GR.

C Didymium dubium Rostaf. 48947...; [fc - 4, mc - 3]. Loc. 1 (4), 9 (2). I: 1-Lar. (b), 3 - grasses (l). IV: 2 - Sal. (w), 1 - on grass litter collected by lemming for their dens (l). - KP, YP, AL, GR.

$\mathrm{R}$ Didymium melanospermum (Pers.) T. Macbr. 49247; [mc]. Loc. 4. III: 1 -Dus. (w). In contrast to other Didymium species with a preference for litter and dung, this species typically occurs on moss-covered coarse woody debris, more rarely on litter. - FL, PU, CP, AL.

R Didymium squamulosum (Alb. \& Schwein.) Fr. 49100, 49246; [mc - 2]. Loc. 4 (1), 7 (1). II: 1 Dus. (1). IIII: 1 -Sal. (1). - FL, YP, CP, AL, GR.

C Echinostelium brooksii K.D. Whitney 1980 49256...; [mc-8]. Loc. 1 (1), 2 (4), 4 (1), 5 (1), 7 (1). I: 2 - Lar. (w), 1 - Lar. (b), 1 -Sal. (b). II: 1 - Lar. (w), 1 - Lar. (b), 1 - Sal. (b). III: 1 - Lar. (w). - IC.

All of our specimens fit the description given by Whitney (1980) except that the spores rarely show a thinner area in the wall. The columella is lenticular and is borne on a short cylindrical projection of the stipe that reaches $4-8 \mu \mathrm{m}$ in diameter and $2-4 \mu \mathrm{m}$ in height. The spores are minutely spinulose (Fig. $5 \mathrm{~F}$ ) and $10-12 \mu \mathrm{m}$ in diameter. This species, regarded as rare, was found surprisingly often in moist chambers, preferentially on the acidic bark of Larix (pH 3.8-5.5; mean 4.3 \pm 0.7).

A Echinostelium minutum de Bary 49116...; [mc-60]. Loc. 1 (15), 2 (15), 3 (1), 4 (3), 5 (10), 7 (13), 8 (1), 9 (2). I: 1 -Bet. (w), 2-Dus. (w), 3-Lar. (w), 2 -Pic. (w), 3-Sal. (w), 3-Sal. (b), 1-Dus. (1). II: 8 - Lar. (w), 2 -Dus. (w), 1 - Sal. (w), 1 Dus. (b), 2 - Lar. (b), 1 - Sal. (b), 5 - Dus. (1), 1 lemming (d). IIII: 9 -Dus. (w), 3 - Lar. (w), 1 - Sal. (w), 1-Dus. (b), 2-Lar (b), 2-Sal. (b), 3-Dus. (1). IV: 2 - Sal. (w). V: 1 - Sal. (b). On the Taimyr Peninsula this was the most common corticolous species ( $\mathrm{pH} 3.3-6.1$, mean $4.5 \pm 0.8$ ). Together with the previous species, these seem to be the only two species of the genus with a preference for acidic substrata. - IC, KP, PU, YP, CP, AL, GR.

This very common and easily recognised species occurs in Taimyr collections in white or cream forms only. The pink form often reported by other workers was never observed.

O Enerthenema papillatum (Pers.) Rostaf. 48925 ...; [fc-1, mc-5]. Loc. 1 (1), 2 (4), 7 (1). I: 1 -Pic. (w), 1-Lar. (w), 2-Lar. (b). III: 1 -Lar. (w). III: 1 - Lar. (w). A rather common species on moderately to strongly decayed coniferous wood, more rarely on bark of living Larix. - IC, FL, PU, CP, AL, GR.

- Enteridium splendens var. juranum (Meylan) Härk. 48952, 48963, 48967; [fc-3]. Loc. 1 (3). I: 2 -Dus. (w). III: 1 - Lar. (w). All fruitings were from relatively dry but larger logs and branches; this is one of the first wood-inhabiting species to appear in the year. - IC, GR.

R Hemitrichia abietina (Wigand) G. Lister 48934, 49226; [fc-1, mc-1]. Loc. 2 (1), 5 (1). III: 2 - Lar. (w). Previously not known from the Arctic.

Sporocarps short-stalked, subglobose or turbinate, $0.5-0.9 \mathrm{~mm}$ in diameter, shining, yellow to orange. Peridium thin, membranous, iridescent. Spores bright yellow in mass, light yellow by transmitted light, verrucose, $10-12 \mu \mathrm{m}$. This species approaches Trichia lutescens in habit but exhibits a capillitium structure typical for Hemitrichia.

- Lamproderma sauteri Rostaf. 48951, 48955, 48958; [fc - 3]. Loc. 1 (3). I: 1 - grasses (1). IIII: 1 Dus. (w), 1 - grasses (1). Found at south-exposed slopes on litter of Duschekia. A common and variable nivicolous species, abundant in the temperate and boreal zones but still with only a few reports from Scandinavia (Fries 1912) and southern and central Finland (Härkönen 1979b). Often found in nivicolous situations (Novozhilov \& Schnittler 1997) this species is one of the snowbank myxomycetes and may be one of the northernmost species in this group. Our records were all weathered and must have developed in spring, thus indicating a nivicolous situation during growth. - IC, KP, GR.

R Leocarpus fragilis (Dicks.) Rostaf. 49187; [mc]. Loc. 5. II: 1 -Dus. (1). - IC, KP, PU, CP, AL, GR.

C Licea belmontiana Nann.-Bremek. 49127...; [mc-10]. Loc. 1 (4), 2 (1), 4 (1), 5 (1), 7 (2), 8 (1). I: 1 - Lar. (b). III: 1 - Lar. (w), 1 - Lar. (b). III: 1 -Dus. (w), 2 - Lar. (w), 1 - Jun. (b), 3 -Dus. (1). New for the Arctic.

The distinguishing characteristics of this species are the smooth peridium without tubercles, the apical plate acting as a lid and the basal plates 
forming petaloid lobes, as well as the dark brown spore-mass with spores rosy to brown under transmitted light, reaching only $10-13 \mu \mathrm{m}$ in diameter. The characters of our specimens match the type specimen of L. belmontiana (NEB 5879). D. Mitchell (pers. comm.) questioned the identity of our specimens but stated that they fit L. belmontiana better than any other species. Colour, size, and ornamentation of the spores and the ornamentation of the inner surface of the peridium are similar to $L$. denudescens Keller \& Brooks. However, L. denudescens differs from our specimens in having a thicker outer layer of the peridium that is gelatinous in consistency when moist, finally weathering away by exposure to rain over a period of time. In this species, the moist sporangium has the appearance of a shiny golden brown ball in a drop of clear gelatine (Keller \& Brooks 1977). In addition, the peridium of $L$. denudescens dehisces irregularly, lacking distinct ridges and platelets (Fig. $3 \mathrm{E}-\mathrm{H}$ ). Our specimens of $L$. belmontiana differ from other species of Licea with petaloid dehiscence and smooth spores (e.g., L. tuberculata, L. castanea, and $L$. nigromarginata) by having a thin but double-layered peridium, a deep olive to light olive brown coloration under transmitted light, lacking tubercles (pegs) along the edges of platelets, and having larger spores. Both Licea castanea and L. nigromarginata have platelet margins with pronounced tubercles, whereas $L$. tuberculata has a black, strongly tuberculous peridium, a yellow-brown spore-mass, and spores 9-11 $\mu \mathrm{m}$ in diameter.

O Licea kleistobolus G.W. Martin 49110...; [mc-6]. Loc. 2 (3), 5 (2), 7 (1). I: 1 - Lar. (w), 1 Lar. (b). II: 2 - Lar. (w), 1 - Dus. (1). III: 1 - Lar. (w). The species as a whole is almost cosmopolitan and rather common in the boreal zone (Schnittler \& Novozhilov 1996) but evidently rare in the Arctic. - PU, CP, AL.

Collections 7123 and 7357 differ from the typical expression of this species by having ambercoloured fructifications and very small spores of (6.6-)7.0-7.5(-8.0) $\mu \mathrm{m}$ in diameter. In this form, the sporocarps are tiny, $(0.08-) 0.1-0.12(-0.15)$ $\mathrm{mm}$ in diameter, sessile on a broad base, globosedepressed, and always completely round in shape. This very inconspicuous form was found twice on decorticated, moderately decayed Larix logs.

A Licea minima Fr. 49103...; [mc - 19]. Loc. 1
(4), 2 (9), 4 (1), 5 (2), 7 (2), 10 (1). I: 1 - Dus. (w), 7 - Lar. (w), 1 - Pic. (w), 1 -Sal. (w), 1 - Jun. (b), 1 - Lar. (b). II: 2 - Lar. (w), 1 - Sal. (w), 1 - Lar. (b). IIII: 1 -Sal. (b), 1 - hare (d). IV: 1 - Sal. (1). One of the most common and abundant species in the Arctic, inhabiting woody, mostly acidic debris ( $\mathrm{pH}$ measured in four moist chambers: 3.6-3.9, mean $3.7 \pm 0.1$ ). $-\mathrm{IC}, \mathrm{FL}, \mathrm{KP}, \mathrm{YP}, \mathrm{CP}, \mathrm{AL}, \mathrm{GR}$.

Our specimens have the typical characters of this species. The firm and brittle peridium consists of 2-3 closely adherent layers and appears red-brown in transmitted light. The outer membranous layer is dark or dull due to the presence of inclusions, the dense and homogeneous middle layer is up to $2 \mu \mathrm{m}$ thick and more or less smooth in texture, whereas a third, inner layer with a shining surface is ornamented with tiny warts, globules and tubercles near the dehiscence line. The spores are red-brown in mass, concolorous by transmitted light, thick-walled with a paler area, verruculose, and $10-13 \mu \mathrm{m}$ in diameter.

A Licea testudinacea Nann.-Bremek. 49095...; [mc-18]. Loc. 1(5), 2 (5), 5 (4), 7 (3), 9 (1). I: 2 -Lar. (w), 1-Pic. (w), 2-Sal. (w), 1 -Sal. (b). III: 2 -Dus. (w), 1 - Sal.(w), 1 - Sal. (b), 1-Dus. (1). IIII: 1 -Dus. (w), 1 -Lar. (w), 1 - Sal. (w), 1-Sor. (w), 1 -Sal. (b), 1 -Dus. (1). IV: 1-Sal. (w).

Our records are the first for the Arctic, but this species may be more widespread. Since it strongly resembles L. minima, it may be confused with this species. Licea testudinacea reported from Iceland, but Gøtzsche's (1990) comments on the Icelandic specimens strongly indicate that they may represent L. minima.

Our material is quite typical except for the spores, which are somewhat smaller than usually described for the species (11-15 $\mu \mathrm{m})$. Licea testudinacea appears to be most closely related to $L$. minima and $L$. chelonoides. It is distinguished from L. minima by the darker, more olive and not rusty-coloured spore mass. In the latter species, the spores are always reddish brown by transmitted light and the peridium has two or three layers. Licea chelonoides differs by having dull black sporocarps not shining when dry, platelet margins with 5 or more rows of tubercles, and spores measuring $15-18 \mu \mathrm{m}$ in diameter.

- Lycogala epidendrum (L.) Fr. 48941, 48954, 48975, 48984; [fc - 4]. Loc. 1(2), 2 (1), 5 (1). I: 1 Lar. (w), 1 - Lar. (w). III: 1 - Lar. (w), 1 - Pic. (w). Widely distributed but uncommon in the Arctic. 

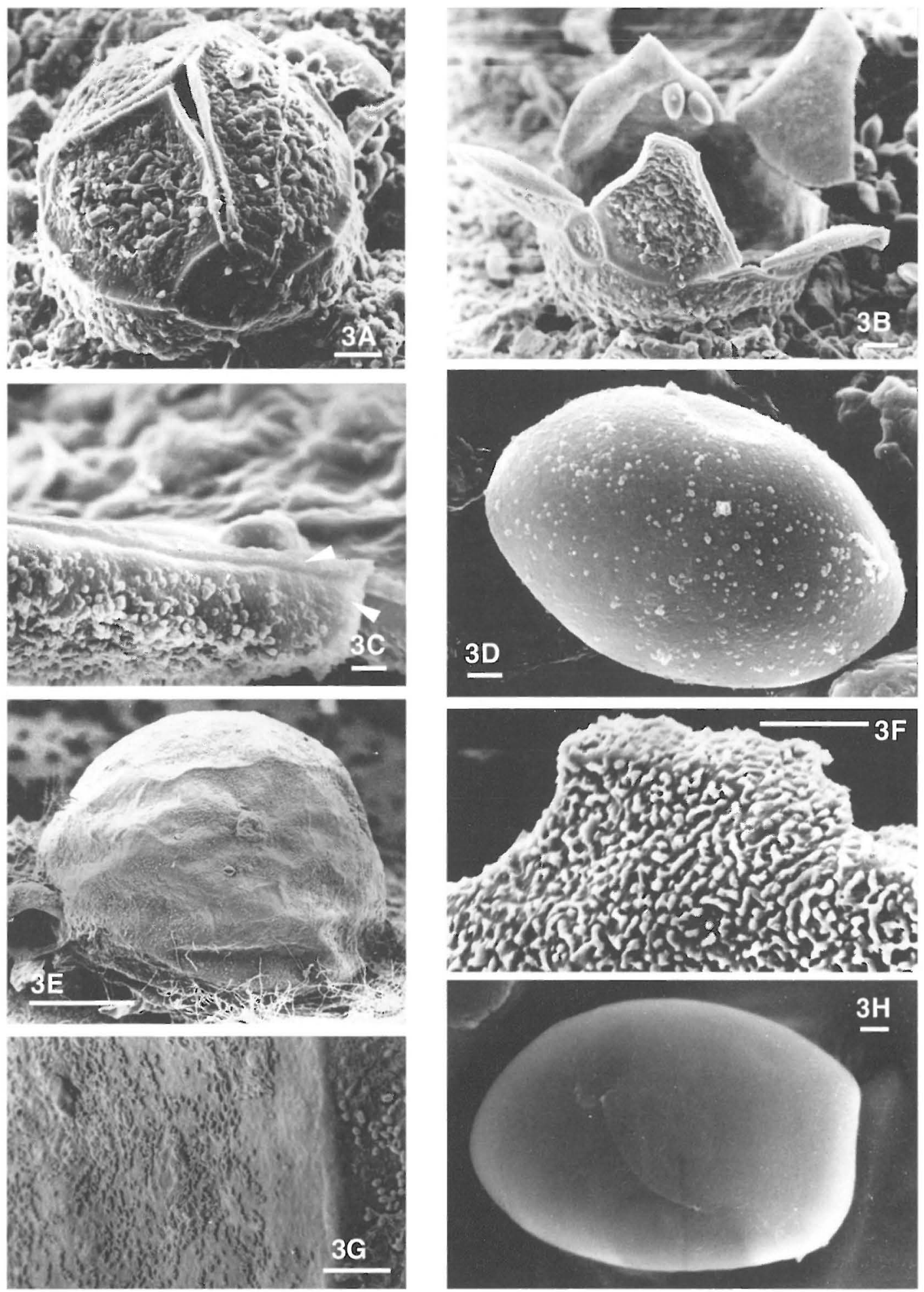

Fig. 3. SEM-photos of Licea belmontiana (LE 49175), A - D, and L. denudescens (Keller, HWK 2754), E - H. A) Closed sporocarp of L. belmontiana. Bar $=10 \mathrm{~mm}$. B) Opened sporocarp. Bar $=10 \mathrm{~mm}$. C) Double-layered peridium and ornamentation present on the inner surface near the preformed line of dehiscence (peridium layers are shown by arrows). Bar $=1 \mathrm{~mm}$. D) Spore. Bar $=1 \mathrm{~mm}$. E) Closed sporocarp of $L$. denudescens. Bar $=10 \mathrm{~mm}$. F) Ornamentation of the inner surface of peridium. Bar $=1 \mathrm{~mm} . \mathrm{G}$ ) Ornamentation of the outer surface of peridium. $\mathrm{Bar}=10 \mathrm{~mm}$. $\mathrm{H}$ ) Spore. $\mathrm{Bar}=1 \mathrm{~mm}$. 

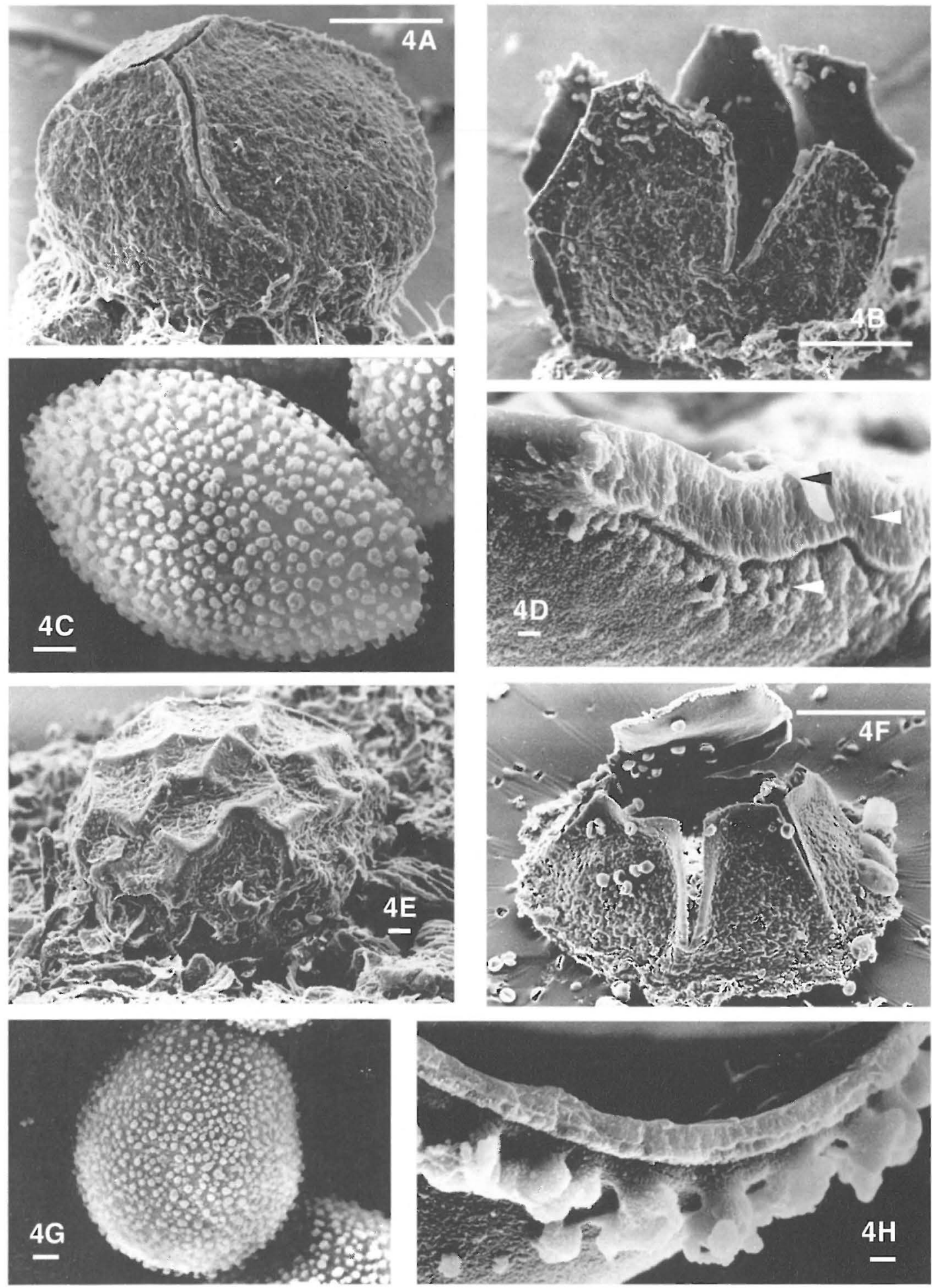

Fig. 4. SEM-photos of Licea minima (LE 49124), A - D, and L. testudinacea (LE 49132), E - H. A) Closed sporocarp of L. minima. Bar $=100 \mathrm{~mm}$. B) Opened sporocarp. Bar $=100 \mathrm{~mm}$. C) Spore. Bar $=1 \mathrm{~mm}$. D) Threelayered peridium and ornamentation present on the inner surface near the preformed line of dehiscence (peridium layers are shown by arrows). Bar $=1 \mathrm{~mm}$. E) Closed sporocarp of L. testudinacea. Bar $=10 \mathrm{~mm}$. F) Opened sporocarp. Bar $=100 \mathrm{~mm}$. G) Spore. Bar =1 mm. H) One-layered peridium and ornamentation of the inner surface near the preformed line of dehiscence. $\mathrm{Bar}=1 \mathrm{~mm}$. 

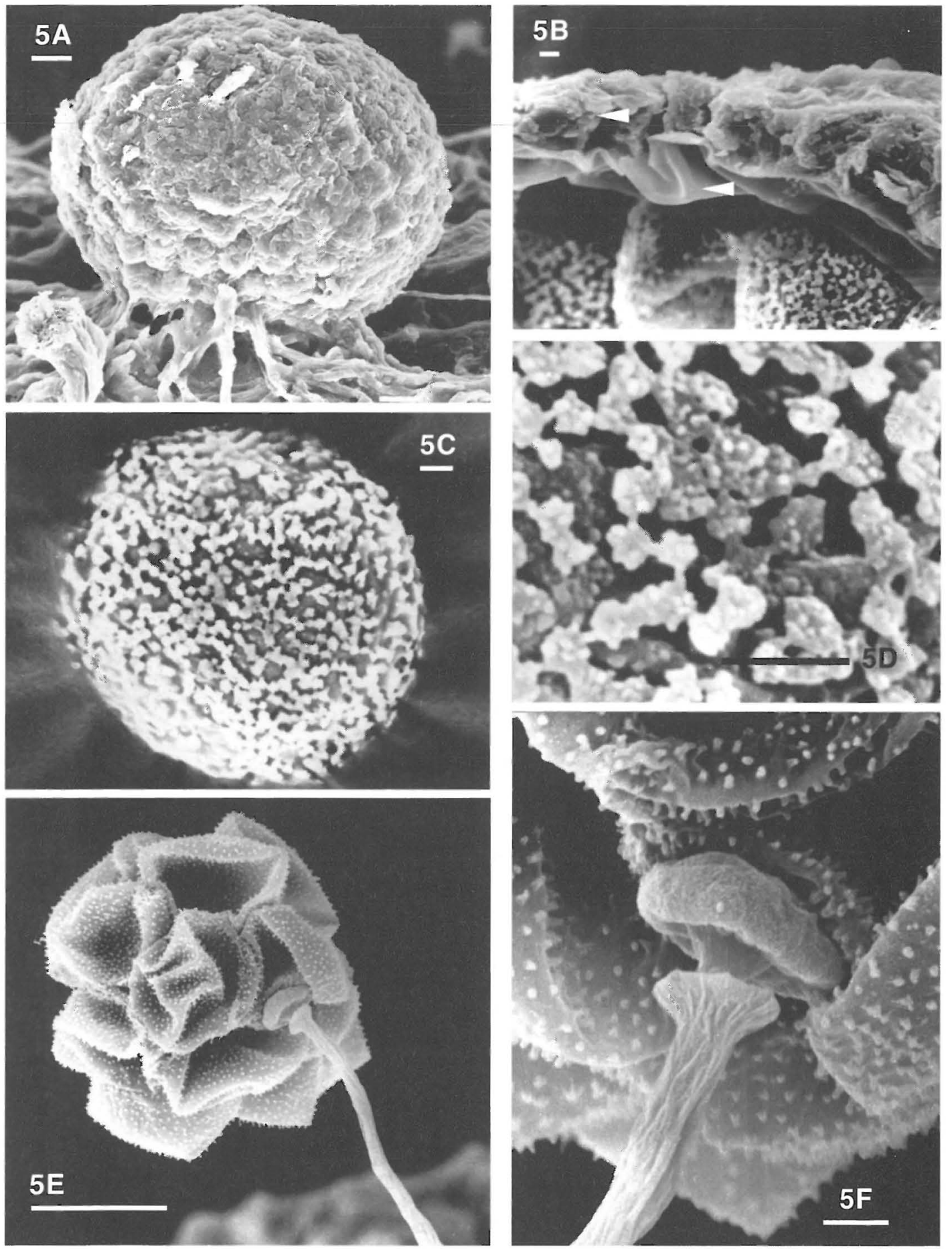

Fig 5. SEM-photos of Perichaena sp. (LE 204007), A - D, and Echinostelium brooksii (sc 7314), E - F. A) Sporocarp with numerous large tubercules. Bar $=10 \mathrm{~mm}$. B) Double-layered peridium. The outer layer of the peridium is closely adherent to the membranous inner layer (peridium layers are shown by arrows). Bar $=1 \mathrm{~mm}$. C) Spore. Bar $=1 \mathrm{~mm}$. D) Spore ornamentation. Bar $=1 \mathrm{~mm}$. E) Whole sporocarp of E. brooksii. Bar = $10 \mathrm{~mm}$. F) Lenticular columella with adjacent collapsed and minutely spinulose spores. Bar $=1 \mathrm{~mm}$. 
Seemingly, the availability of coarse woody debris probably limits the northern distribution of this species. The Spitsbergen record was on the remnants of a log house (Elvebakk et al. 1996). IC, Spitsbergen, FL, KP, PU, CP, AL, GR.

O Macbrideola cornea (G. Lister \& Cran) Alexop. 49111, 7349, 7358; [mc-3]. Loc. 2(1), 5 (1), 7 (1). II: 1 -Sal. (b), 1 - polar partridge (d). III: 1 - Sal. (1). - PU, GR. Fruiting typically on the bark of living trees and shrubs, our record from dung is unusual although not the only one for this species from this substratum (Eliasson \& Keller 1999).

- Mucilago crustacea F.H. Wigg. 48946; [fc]. Loc. 5. III: 1 - grasses (1). Our record comes from a moss- and grass-rich, open patch of the foresttundra. Probably a soil myxomycete, in temperate zones fruiting in meadows and herbfields. Apparently not restricted to wood or litter, it may be one of the few species inhabiting typical tundra, as indicated also by findings from Alaska (Stephenson \& Laursen 1993). - IC, FL, PU, CP, AL, GR.

R Paradiacheopsis cf. cribrata Nann.Bremek. 49163, 7197; [mc-2]. Loc. 2 (1), 5 (1). I: 1 - Lar. (w). II: 1 - Lar. (b). - IC.

This is an extremely variable species. As reported by Härkönen (1977), the complex of small, Comatricha-like species is very difficult to resolve taxonomically. Our collections differ slightly from each other in the development of the surface net but are separated from the very common Comatricha nigra by duller spore colour, smaller size, shorter stalks and a rigid capillitium anastomosing to form an incomplete surface net.

A Paradiacheopsis fimbriata (G. Lister \& Cran) Hertel 49134...; [mc-20]. Loc. 2 (11), 3 (1), 4 (4), 5 (4). I: 4 - Lar. (w), 3 -Lar. (b). III: 6-Lar. (w), 7 - Lar. (b). Found always on living and coarse woody debris of Larix; with a clear preference for its acidic bark ( $\mathrm{pH}$ from 11 moist chambers: 3.45.7, mean 3.9 \pm 0.7 ). - FL, PU, CP.

O Perichaena chrysosperma (Currey) Lister 49099...; [mc - 6]. Loc. 1 (1), 2 (5). I: 1 - Lar. (w), 1 - Sal. (w), 1 - Sal. (b). II: 1 - Sal. (b), 1-Dus. (1). III: 1 - Sor. (w), 1 - Sal. (b). This species develops in the litter layer on even tiny wood fragments such as the dead branchlets of shrubs. A widespread corticolous species. - IC, PU, CP, AL, GR.

R Perichaena depressa Libert 49218, 49233; [mc-2]. Loc. 4 (1), 5 (1). II: 2 - polar partridge (d).
Dung as a second microhabitat seemingly allows this species to extend its range farther northwards. Almost cosmopolitan in distribution, but in the Arctic recorded only from the Chukchi Peninsula and Alaska.

R Perichaena sp. 204007, 204181; [mc - 2]. Loc. 3 (2). II: 2 - reindeer (d).

Sporocarps crowded, gregarious or scattered, globose to subglobose, pulvinate to elongated, $0.2-0.7 \mathrm{~mm}$ in diameter. Sessile on a constricted base, not iridescent but glossy and shining, buffyellow, orange-yellow to apricot-orange, dehiscing more or less irregularly. Peridium persistent, double; outer layer closely adherent to the membranous inner layer, rough, bearing numerous large tubercles, more or less cartilaginous, brittle, fairly evenly thick, probably without lime, yellow-brown in transmitted light, shining, opaque with granular deposits. Inner layer membranous, rather elastic, thin, delicate, translucent in transmitted light, limeless. Hypothallus inconspicuous, scanty. Capillitium absent. Spores orangeyellow, yellowish brown, honey yellow, or orange-golden in mass, bright to buff yellow in transmitted light, globose, wall of uniform thickness and colour, neither areolate nor with a germination pore, minutely roughened (asperulate) under an oil immersion lens, or verruculose (delicately warted), complete and evenly ornamented, $14.0-15.0 \mu \mathrm{m}$ in diameter. The epispore belongs to the pilate type (Rammeloo 1974). Verrucae consist of small pila which are more or less evenly distributed on the spore surface; the capita of pila are separate or sometimes connected to one another and relatively large, $0.1-0.4 \mu \mathrm{m}$ wide, with 3-6 small tubercles.

Our specimens differ strongly from all other coprophilous species of Licea and Perichaena with a golden-yellow spore mass. In habit and sporocarp size they resemble Perichaena liceoides Rostaf. emend Gilert and L. tenera Jahn. The main differences between these species and the Taimyr specimens are spore size and ornamentation. Perichaena liceoides has spores 9.2$10 \mu \mathrm{m}$ in diameter which are evenly covered with prominent spines (Gilert 1990, Ukkola et al. 1996). According to the original description (Jahn 1918), L. tenera has faintly spinulose spores, 10 $12(-13) \mu \mathrm{m}$ in diameter and with a thinner-walled area on one side. Our specimens approach some Licea species not only in general habit but also in the absence of a capillitium. However, the pres- 
ence or absence of a capillitium as a taxonomically important character has been questioned (Alexopoulos 1976; Eliasson 1977; Keller \& Brooks 1971). We assume that the Taimyr specimens represent another taxon intermediate between Perichaena and Licea. It can be tentatively placed within the facultatively fimicolous group of species within the genus Perichaena that includes $P$. chrysosperma, $P$. depressa, $P$. minor, $P$. pedata, $P$. quadrata, and $P$. corticalis var. liceoides (Eliasson \& Keller 1999; Keller \& Eliasson 1992).

O Perichaena vermicularis (Schwein.) Rostaf. 7208, 7209, 7377, 7367, 48957; [fc-1, mc-4]. Loc. 1 (1), 2 (2), 4 (1), 5 (1). I: 1 - grasses (1), 1 Sal. (w). II: 1 -Dus. (w), 1 - Lar. (w), 1 - Sal. (b). Cosmopolitan, but apparently less common than P. chrysosperma in the Arctic. - AL, GR.

Our collections consist of two ecological forms. All specimens on decayed wood and bark of living trees and shrubs are typical for the corticolous form of this species, having a rather thick, dark brown peridium, and scanty capillitium. In contrast, the field collection from grassy litter shows a membranous, thin peridium and numerous elastic capillitial threads consisting of filaments $2.0-3.0 \mu \mathrm{m}$ in diameter, densely ornamented with warts and short spines. The primary ornamentation of the inner surface of the peridium consists of rather sparse warts of irregular form, up to $0.5 \mu \mathrm{m}$ wide.

C Physarum bivalve Pers. 49118...; [mc - 7]. Loc. 1 (1), 2 (4), 7 (2). I: 2 - Dus. (1), 1 - hare (d). II: 1 - Sal. (1). IIII: 3 -Dus. (1). One of the few almost ubiquitous litter species, widely distributed in the boreal zone and the Arctic on leaf litter and dung of herbivorous animals. - KP, CP, AL.

- Physarum cinereum (Batsch) Pers. 48973; [fc]. Loc. 1 (1). I: 1 - grasses (1), the typical form not intermediate to $P$. vernum. Widely distributed in the Arctic but less abundant than the previous species, occurring mainly on living plants and different types of litter substrata. - IC, KP, CP, AL, GR.

O Physarum cf. nudum T. Macbr. 49164, 49192, 7138, 7205, 7220; [mc - 5]. Loc. 1 (1), 2 (1), 5 (1), 7 (2). I: 2 -Lar. (b). III: 1 - Lar. (b). III: 2 - Lar. (b). For the Arctic, up to now found only on the Taimyr Peninsula.

Three collections are immature, but two (7138, 49192) are mature, consisting of numerous, crowded but not heaped sporocarps, or (very seldom) short plasmodiocarps that are $0.3-0.5$ $\mathrm{mm}$ wide and globose in cross-section, sessile with a restricted base on an inconspicuous hypothallus. Capillitium a dense, three-dimensional network of translucent, colourless and often flattened threads $2-3(-10) \mu \mathrm{m}$ in diameter, with numerous elongated but very inconspicuous and not sharply separated, ash-grey nodes of granular lime $20-50 \mu \mathrm{m}$ in length. Spores violaceousbrown in mass, globose, very pale violaceous grey under transmitted light, ornamented with slightly irregularly distributed, very fine warts less than $0.15 \mu \mathrm{m}$ in height but visible clearly under an oil immersion lens, (8.1-)8.5-9.7(-10.5) $\mu \mathrm{m}$ in diameter. Our specimens agree with the description of $P$. nudum and cannot be placed elsewhere with more certainty. They could be confused with a limeless form of $P$. cinereum, but the latter species is found in a different microhabitat (litter).

O Physarum nutans Pers. 48910...; [fc - 2, mc3]. Loc. 1(1), 2 (3), 5 (1). I: 1 - Pic. (w), 1 - Lar. (b). II: 2 - Lar. (w), 1 - Pic. (w). - FL, PU, CP, GR.

R Physarum oblatum T. Macbr. 49193, 7130; [mc-2]. Loc. 2 (2). I: 2 - Sal. (w). Rather rare in in the Arctic. - AL, CP.

R Physarum viride (Bull.) Pers. 49124; [mc]. Loc. 5. III: 1 - Lar. (w). Rarely recorded from moist chambers and perhaps underrepresented in our survey, which was carried out in June. - FL, PU, $\mathrm{KP}, \mathrm{CP}$.

O Prototrichia metallica (Berk.) Massee 49117, 49122, 49123, 49185; [mc - 4]. Loc. 2 (1), 5 (2), 7 (1). I: 1 - Lar. (w). II: 2 -Lar. (w). III: 1 - Lar. (w). $-\mathrm{CP}, \mathrm{GR}$.

One of the northernmost records for this species.

- Stemonitis axifera (Bull.) T. Macbr. 48962, 48968; [fc-2]. Loc. 1 (2). I: 1 - Pic. (w). III: 1 grasses (1). - PU, KP, CP, AL.

-Stemonitis smithii T. Macbr. 48969; [fc]. Loc. 1. II: 1 - Pic. (w). - KP, AL.

$\mathrm{R}$ Stemonitopsis subcaespitosa (Peck) Nann.-Bremek. 7191, 7364; [mc-2]. Loc. 1 (2). III: 2 -Dus. (w). In the Arctic so far known only from the Taimyr Peninsula.

Characteristic features of this species are the small but cylindrical, reddish brown sporocarps 2-2.5 mm in height, and a surface net consisting of sinuous threads with meshes (10-)15-35 $\mu \mathrm{m}$ wide. Comparison with authentic material collected by Hagelstein in eastern North America re- 
vealed a similarity for all characters except the slightly smaller spores that are (7.0-)-7.5-7.8(8.0) $\mu \mathrm{m}$ in diameter.

R Trichia botrytis (J.F. Gmel.) Pers. 49130, 49183; [mc-2]. Loc. 2(1), 5 (1). I: 1 - Lar. (w). III: 1 - Dus. (w). Widely distributed in the boreal and arctic zones. $-\mathrm{IC}, \mathrm{PU}, \mathrm{KP}, \mathrm{CP}$.

R Trichia decipiens (Pers.) T. Macbr. 49194; [mc]. Loc. 4. II: 1 - Dus. (1). One of the most common and abundant species in the boreal zone, perhaps underrepresented in our survey. - IC, FL, KP, CP, AL, GR.

R Trichia lutescens (Lister) Lister 49101, 7366; [mc-2]. Loc. 5 (2). III: 1 - Dus. (b), 1 - Dus. (1). Widely distributed but uncommon in the boreal and arctic zones. - IC, FL, PU, CP, AL, GR.

O Trichia munda (Lister) Meylan 49113...; [mc -5]. Loc. 1 (1), 2 (2), 4 (1), 7 (1). I: 1 - Lar. (w), 1 Dus. (1). II: 1 -Dus. (1). III: 1 -Bet. (1). V: 1 -Sal. (b). Typically, the first sporocarps appear in moist chamber culture only after one or two months on very wet litter, often directly under a thin water film. Rare elsewhere, this species is surprisingly often recorded in the Arctic, always on leafy litter. - IC, PU, YP, CP, AL, GR.

This species resembles $T$. botrytis, to which it is probably most closely related. Our material agrees well with the description of specimens from Iceland and Greenland (Gøtzsche 1989, 1990).

O Trichia varia (Pers.) Pers. 48901...; [fc - 4, mc - 1]. Loc. 1 (1), 2 (3), 5 (1). I: 1 - Lar. (w), 1 Pic. (w). II: 2 - Lar. (w), 1 -Dus. (1). Widely distributed and abundant in boreal and arctic regions on decayed wood. - IC, FL, PU, YP, CP, AL, GR.

\section{Results and discussion}

Our survey is the first systematic study of myxomycetes of north-central Siberia carried out with the moist chamber technique. Data on the frequency of myxomycetes on various substrata are given in Table 1. Substrata were classified as follows: coarse woody debris (decaying logs, branches, and twigs more than $2.5 \mathrm{~cm}$ in diameter, hereafter referred to as "wood"), litter of various types (leaves, grasses, dead stems of herbaceous plants), and dung of herbivorous animals. From the 270 moist chamber cultures prepared, 331 collections and 48 species were obtained in 145 (54\%) cultures positive for myxomycetes
(Table 2).

The mean value for the number of species per moist chamber culture was calculated as $1.22 \pm$ 0.09 . The most productive substratum was wood, preferentially logs, trunks and snags of trees and larger shrubs. Sixty-four (66\%) of 97 moist chamber cultures prepared with wood were positive for myxomycetes. From 80 cultures prepared with the bark of living trees and shrubs, 51 (64\%) were positive for myxomycetes. Various types of litter samples were used to prepare 63 moist chamber cultures; $23(37 \%)$ of these yielded myxomycetes. From 30 moist chamber cultures prepared with animal droppings, only 7 (23\%) were positive.

Transportation opportunities confined our survey time to June and July of the years 1995 and 1996, which is definitely earlier than the peak fructification period of most wood-inhabiting myxomycetes. Only 39 field collections representing 19 species were obtained and 8 of these species were found exclusively in the field. As such, our total of 56 species in 26 genera represents only a preliminary account of the myxomycete biota of the region, which undoubtedly could be supplemented by records of numerous wood-inhabiting species.

\section{Myxomycete habitats}

Very often, arctic and subarctic regions are perceived as a monotonous landscape with a limited number of vascular plants and a dominance of cryptogams. But even the few taller plants present form numerous microhabitats with different conditions of soil, mesoclimate, microclimate, and microrelief. As a result, thus, the microhabitat diversity in arctic landscapes is almost comparable to that of boreal regions (Chernov \& Matveyeva 1997). However, most substrata, especially woody ones, are present at a much lower density. In spite of the scarcity of trees, the foresttundra as well as the northern taiga provides all microhabitats typically found in boreal forests, but most of the substrata are less sheltered from wind, rain, and direct sunlight. The quantity and quality of microhabitats suitable for myxomycete growth and development decrease considerably northwards to the southern and typical tundra. The most striking difference is the reduction in coarse woody debris, including logs, trunks and snags north of the timberline. The southern tundra is characterised by tall shrub communities in sheltered places, on the Taimyr Peninsula consisting mainly in Duschekia fruti$\cos a$ and different species of willows having 
Table 1. Occurrence of myxomycetes on various types of substrata collected from all vegetation subzones of the Taimyr Peninsula. Data from southern tundra, typical tundra, arctic tundra and mountain tundra were combined in one set. Single numbers or numbers before a slash indicate records from moist chamber cultures, those after a slash represent collections made in the field. Abbreviations used for the substrata are: w-coarse woody debris, 1-litter, b-bark of living trees and shrubs, and d-dung of herbivorous animals.

\begin{tabular}{|c|c|c|c|c|c|c|c|c|c|c|c|c|c|}
\hline \multirow[t]{2}{*}{ Species } & \multicolumn{4}{|c|}{ Taiga } & \multicolumn{4}{|c|}{ Forest tundra } & \multicolumn{4}{|c|}{ Tundra } & \multirow[t]{2}{*}{ Total } \\
\hline & w & 1 & $\mathrm{~b}$ & d & W & 1 & $\mathrm{~b}$ & $\mathrm{~d}$ & w & 1 & $\mathrm{~b}$ & $\mathrm{~d}$ & \\
\hline Arcyria cinerea & 9 & 1 & 5 & & 6 & 3 & 2 & & $5 / 1$ & 2 & 7 & 2 & 43 \\
\hline Arcyria denudata & 2 & & & & & & & & & & & & 2 \\
\hline Arcyria incarnata & $7 / 1$ & & 1 & & 3 & & & & 3 & & & & 15 \\
\hline Arcyria obvelata & $1 / 1$ & & & & & & & & & & & & 2 \\
\hline Arcyria pomiformis & 2 & & & & 1 & & & & & & & & 3 \\
\hline Arcyodes incarnata & & & & & 1 & & & & & & & & 1 \\
\hline Calomyxa metallica & 1 & & & & & & & & & & & & 1 \\
\hline Ceratiomyxa fruticulosa & $2 / 2$ & & & & 1 & & & & 1 & & & & 6 \\
\hline Comatricha laxa & 1 & & & & & & & & & & & & 1 \\
\hline Comatricha nigra & $3 / 3$ & & 10 & & $4 / 1$ & 1 & 14 & & $3 / 1$ & & 7 & & 47 \\
\hline Comatricha pulchella & 1 & & & & & & & & & & & & 1 \\
\hline Craterium leucocephalum & & & & & & & & & 1 & & & & 1 \\
\hline Cribraria cf. atrofusca & 1 & & & & & & & & & & & & 1 \\
\hline Cribraria microcarpa & 2 & & & & 2 & & & & & & & & 4 \\
\hline Cribraria violacea & 2 & & 1 & & & & 1 & & & & & & 4 \\
\hline Cribraria vulgaris & & & & & 1 & & & & & & & & 1 \\
\hline Diderma radiatum & & & & & 1 & & & & & & & & 1 \\
\hline Didymium difforme & & & & & & & & 1 & & & & & 1 \\
\hline Didymium dubium & & 3 & 1 & & & & & & $-/ 2$ & 1 & & & 7 \\
\hline Didymium melanospermum & & & & & 1 & & & & & & & & 1 \\
\hline Didymium squamulosum & & & & & & 1 & & & & 1 & & & 2 \\
\hline Echinostelium brooksii & 2 & & 2 & & 1 & & 2 & & 1 & & & & 8 \\
\hline Echinostelium minutum & 11 & 1 & 3 & & 11 & 5 & 4 & 1 & 15 & 3 & 6 & & 60 \\
\hline Enerthenema papillatum & 2 & & 2 & & $-/ 1$ & & & & 1 & & & & 6 \\
\hline Enteridium splendens var. juranum & -12 & & & & & & & & $-/ 1$ & & & & 3 \\
\hline Hemitrichia abietina & & & & & $1 / 1$ & & & & & & & & 2 \\
\hline Lamproderma sauteri & & $-/ 1$ & & & & & & & $-/ 1$ & $-/ 1$ & & & 3 \\
\hline Leocarpus fragilis & & & & & & 1 & & & & & & & 1 \\
\hline Licea belmontiana & & & 1 & & 1 & & 1 & & 3 & 3 & 1 & & 10 \\
\hline Licea kleistobolus & 1 & & 1 & & 2 & 1 & & & 1 & & & & 6 \\
\hline Licea minima & 10 & & 2 & & 3 & & 1 & & & 1 & 1 & 1 & 19 \\
\hline Licea testudinacea & 5 & & 1 & & 3 & 1 & 1 & & 5 & 1 & 1 & & 18 \\
\hline Lycogala epidendrum & -12 & & & & -12 & & & & & & & & 4 \\
\hline Macbrideola cornea & & & & & & & 1 & 1 & & 1 & & & 3 \\
\hline Mucilago crustacea & & & & & & $-/ 1$ & & & & & & & 1 \\
\hline Paradiacheopsis cf. cribrata & 1 & & & & & & 1 & & & & & & 2 \\
\hline Paradiacheopsis fimbriata & 4 & & 3 & & 6 & & 7 & & & & & & 20 \\
\hline Perichaena chrysosperma & 2 & & 1 & & & 1 & 1 & & 1 & & & & 6 \\
\hline Perichaena depressa & & & & & & & & 2 & & & & & 2 \\
\hline Perichaena sp. & & & & & & & & 2 & & & & & 2 \\
\hline Perichaena vermicularis & 1 & $-/ 1$ & & & 2 & & 1 & & & & & & 5 \\
\hline Physarum cinereum & & $-/ 1$ & & & & & & & & & & & 1 \\
\hline Physarum bivalve & & 2 & & 1 & & 1 & & & & 3 & & & 7 \\
\hline Physarum cf. nudum & & & 2 & & & & 1 & & & & 2 & & 5 \\
\hline Physarum nutans & 1 & & 1 & & $1 / 2$ & & & & & & & & 5 \\
\hline Physarum oblatum & 2 & & & & & & & & & & & & 2 \\
\hline Physarum viride & & & & & 1 & & & & & & & & 1 \\
\hline Prototrichia metallica & 1 & & & & 2 & & & & 1 & & & & 4 \\
\hline Stemonitis axifera & $-/ 1$ & & & & & & & & & $-/ 1$ & & & 2 \\
\hline Stemonitis smithii & $-/ 1$ & & & & & & & & & & & & 1 \\
\hline Stemonitopsis subcaespitosa & & & & & & & & & 2 & & & & 2 \\
\hline Trichia botrytis & 1 & & & & 1 & & & & & & & & 2 \\
\hline Trichia decipiens & & & & & & 1 & & & & & & & 1 \\
\hline Trichia lutescens & & & & & & 1 & 1 & & & & & & 2 \\
\hline Trichia munda & 1 & 1 & & & & 1 & & & & 1 & 1 & & 5 \\
\hline Trichia varia & -12 & & & & -12 & 1 & & & & & & & 5 \\
\hline
\end{tabular}


Table 2. Results obtained from moist chamber cultures prepared with substratum samples collected in the vegetation subzones of the Taimyr Peninsula. Roman numbers written in bold refer to the vegetation subszones as explained in the text.

\begin{tabular}{|c|c|c|c|c|c|c|}
\hline $\begin{array}{l}\text { Vegetation } \\
\text { subzones }\end{array}$ & $\begin{array}{l}\text { Number } \\
\text { of moist } \\
\text { chamber } \\
\text { cultures }\end{array}$ & $\begin{array}{l}\text { Positive } \\
\text { moist } \\
\text { chamber } \\
\text { cultures } \\
\text { ( } \% \text { of } \\
\text { total) }\end{array}$ & $\begin{array}{l}\text { Number of } \\
\text { collections }\end{array}$ & $\begin{array}{l}\text { Number of } \\
\text { species }\end{array}$ & $\begin{array}{c}\text { Average } \\
\text { yield } \\
\text { (species per } \\
\text { moist } \\
\text { chamber) } \\
\text { Mean } \pm \text { SE }\end{array}$ & $\begin{array}{c}\text { Shannon } \\
\text { diversity } \\
\text { index } \\
\left(\mathrm{H}^{\prime}\right)\end{array}$ \\
\hline I Taiga & 55 & $45(82)$ & 122 & 32 & $2.19 \pm 0.26$ & 1.31 \\
\hline Wood (w) & 24 & $21(88)$ & 79 & 28 & $3.54 \pm 0.48$ & 1.26 \\
\hline Litter (1) & 7 & $3(43)$ & 5 & 4 & $0.71 \pm 0.40$ & 0.58 \\
\hline Bark (b) & 21 & $18(86)$ & 37 & 16 & $1.76 \pm 0.23$ & 1.06 \\
\hline Dung (d) & 3 & $1(33)$ & 1 & 1 & $0.33 \pm 0.33$ & 0 \\
\hline II Forest tundra & 110 & $54(49)$ & 119 & 36 & $1.08 \pm 0.12$ & 1.28 \\
\hline Wood (w) & 34 & $21(62)$ & 54 & 22 & $1.66 \pm 0.27$ & 1.24 \\
\hline Bark (b) & 34 & $19(56)$ & 39 & 15 & $1.15 \pm 0.21$ & 0.94 \\
\hline Litter (1) & 25 & $8(32)$ & 19 & 13 & $0.76 \pm 0.28$ & 1.01 \\
\hline Dung (d) & 17 & $4(24)$ & 7 & 5 & $0.41 \pm 0.15$ & 0.67 \\
\hline III-IV Tundra & 105 & $51(49)$ & 90 & 22 & $0.84 \pm 0.10$ & 0.99 \\
\hline Wood (w) & 39 & $22(56)$ & 45 & 15 & $1.13 \pm 0.21$ & 0.98 \\
\hline Bark (b) & 25 & $14(56)$ & 26 & 8 & $1.04 \pm 0.20$ & 0.76 \\
\hline Litter (1) & 31 & $12(39)$ & 16 & 9 & $0.52 \pm 0.14$ & 0.90 \\
\hline Dung (d) & 10 & $2(20)$ & 3 & 2 & $0.30 \pm 0.21$ & 0.28 \\
\hline All subzones & 270 & $145(54)$ & 331 & 48 & $1.22 \pm 0.09$ & 1.32 \\
\hline Wood (w) & 97 & $64(66)$ & 178 & 37 & $1.82 \pm 0.19$ & 1.29 \\
\hline Bark (b) & 80 & $51(64)$ & 102 & 21 & $1.27 \pm 0.13$ & 1.03 \\
\hline Litter (1) & 63 & $23(37)$ & 40 & 16 & $0.63 \pm 0.13$ & 1.05 \\
\hline Dung (d) & 30 & $7(23)$ & 11 & 8 & $0.32 \pm 0.11$ & 0.88 \\
\hline
\end{tabular}

trunks up to $10 \mathrm{~cm}$ thick. But shrub thickets with trunks up to $3 \mathrm{~cm}$ thick may occur even in typical tundra. On the other hand, patches of tundralike vegetation can occur already in the northern taiga on exposed sites. In the lowlands of the Taimyr Peninsula, all subzones differentiated herein on the basis of vegetation structure form a mosaic pattern over wide areas.

Moist chamber cultures prepared with samples of wood yielded 37 species representing 16 genera of myxomycetes. This microhabitat showed the highest diversity $\left(\mathrm{H}^{\prime}=1.29,178 \mathrm{col}-\right.$ lections) and species richness. The mean value for number of species per moist chamber culture prepared with wood was $1.82 \pm 0.19$, with up to 10 taxa per culture (Table 2).

Wood has a wide range of chemical and physical characteristics (Stephenson 1988; Samuelsson et al. 1994). As a result, it can be seen that considerable variation exists among the various species with respect to patterns of substratum relationships. The most common species were Echinostelium minutum (37 collections), Arcyria cinerea (20), Licea minima (13), L. testudina- cea (13), Arcyria incarnata (13), Paradiacheopsis fimbriata (10), and Comatricha nigra (10). Wood-inhabiting species were found surprisingly often on even tiny branchlets. A good example is C. nigra, which was often collected on small, decorticated branchlets of Duschekia or Salix. Echinostelium minutum, Licea spp., and Perichaena spp. were found on small decaying twigs (sometimes only $5 \mathrm{~mm}$ in diameter) or under the exfoliating bark of branchlets intermixed with leafy litter in dense shrub thickets. Thus, the timberline is not an absolute biogeographic "barrier" for wood-inhabiting myxomycetes. Some typically wood-inhabiting species occur far into the tundra, using different types of microhabitats such as litter, twigs, bark of living shrubs, and dung of animals. Arcyria cinerea, Echinostelium minutum, and Perichaena depressa were found sporadically on animal dung. Here, dung as a second microhabitat seemingly allows a particular species to extend its range farther northwards. Wood-inhabiting myxomycetes were found to be the largest ecological group (44 taxa) in spite of the fact that species not regularly occurring in moist chambers are certainly underrepresented in our survey. The species of Trichia illustrate this; all species except $T$. varia were recorded only sporadically from moist chambers but not as field collections. 
Twenty-one species in 12 genera were collected on the bark of living trees and shrubs from 80 moist chamber cultures $\left(\mathrm{H}^{\prime}=1.03,102\right.$ collections). Both a low number of species (21) and a few exceedingly abundant species (e.g., Comatricha nigra: 31 collections) explain the relatively low diversity index value. An average species number of $1.27 \pm 0.13$ per culture, with a maximum of 5 taxa in one moist chamber, was recorded (Table 2).

Larix gmelinii, the most common tree forming the timberline, has a bark $\mathrm{pH}$ of 2.6-4.7 (mean from 46 collections: $3.7 \pm 0.1$ ), followed by Salix spp. with 3.55.9 (mean from 14 collections: $4.8 \pm 0.2$ ), and Duschekia fruticosa with 4.7-6.4 (mean from 9 collections: 5.6 \pm 0.2 ). The two conifers (L. gmelinii and Picea obovata) have a scaly and fissured bark, but species diversity $\left(\mathrm{H}^{\prime}=\right.$ $0.85,81$ collections) was similar to that found for the smooth bark of deciduous shrubs (Duschekia fruticosa and Salix spp., H' $=0.84,32$ collections). However, the species per culture ratio was lower for coniferous bark (mean from 53 cultures: $1.2 \pm 0.2$ ) than for bark from deciduous shrubs $(1.6 \pm 0.3)$. From the 21 species found on bark, only Comatricha nigra (31 records), Echinostelium minutum (13), Arcyria cinerea (11), and Paradiacheopsis fimbriata (10) are predominantly corticolous. Both average yield of moist chambers as well as Shannon diversity indexes are slightly higher than those reported for the acidic bark of coniferous trees (Picea rubens and Tsuga canadensis) in the temperate forests of southwestern Virginia of the United States (Stephenson 1989). Most of the species of myxomycetes encountered in the present study appear to have a relatively wide $\mathrm{pH}$ tolerance but show different $\mathrm{pH}$ optima. As a general observation, corticolous species seem to have more narrow $\mathrm{pH}$ amplitudes than wood-inhabiting species. Comatricha nigra was collected 30 times on the bark of living Larix and Picea but only once on the bark of Duschekia fruticosa; Paradiacheopsis fimbriata was found only on Larix (10 times on bark of living Larix and 10 records from Larix logs); and Physarum cf. nudum appeared exclusively on the bark of Larix. The most probable reason is the low $\mathrm{pH}$ of the bark of all common coniferous substrata samples in the present study.

Sixteen species in 8 genera were collected on litter from 63 moist chamber cultures $\left(\mathrm{H}^{\prime}=1.05,40\right.$ collections, mean $0.63 \pm 0.13$ species per culture). Especially in the tundra, litter plays an important role as a microhabitat, accumulating in deep shade in the southern tundra under dense thickets of Duschekia and Salix up to $1.5 \mathrm{~m}$ tall. But even the wind-sheltering effects of the dwarf shrubs that prevail in the typical and northern tundra is enormous.

Measurements of microclimate conditions associated with the arctic-alpine dwarf shrub Loiseleuria procumbens in the Austrian Alps revealed a reduction of wind velocity from $16 \mathrm{~m} / \mathrm{s}$ at $3 \mathrm{~cm}$ height to almost $0 \mathrm{~m} / \mathrm{s}$ on the ground, a minimum air relative humidity of $80 \%$ even on dry and sunny days, and a pronounced heating effect, enhancing temperatures from $12^{\circ} \mathrm{C}$ on the shrub canopy ( $3 \mathrm{~cm}$ high) to more than $45^{\circ} \mathrm{C}$ on ground (Chernusca 1976). Similar effects can be assumed for the Taimyr Peninsula with its continental climate. Such shrub thickets work as natural moist chambers, especially for litter myxomycetes, allowing them to develop as far north as shrubs occur. Species such as Arcyria cinerea (6 collections), Echinostelium minutum (9), Physarum bivalve (6), and Trichia munda (3) were most abundant in litter cultures. Except Physarum bivalve, all of these species also grow on other substratum types such as wood and bark. One explanation for this phenomenon could be the similar low average $\mathrm{pH}$ of litter $(5.9 \pm 0.1$, 45 samples). However, only the probably nivicole Lamproderma sauteri (2 collections) and Physarum bivalve (6) revealed a clear preference for litter. With only 20 species recorded, the survey for litter-inhabiting myxomycetes is probably incomplete. Detailed investigations of herbfields occurring in wet depressions and along streams in the northern taiga and forest-tundra might well reveal a whole assemblage of litter-inhabiting species. Such communities were seen at the foot of the " Krasnyi Kamen" " hills (locality 1), where a dense cover of herbaceous plants (e.g., Cirsium helenioides and various umbellifers) up to $1 \mathrm{~m}$ tall provides large amounts of soft, decaying plant detritus, often with the hollow stems lying in the dense shade under the new shoots.

Dung-inhabiting myxomycetes are widely distributed within the Arctic (Cox 1981, Gøtzsche 1989, Eliasson \& Keller 1999), but this microhabitat was not very productive in the present study $\left(H^{\prime}=0.88,11\right.$ collections, mean $0.32 \pm 0.11$ species per culture). With only six species recorded from 25 substratum samples, the dung of herbivorous animals was significantly less productive than in arid zones of the world (Blackwell \& Gilbertson 1980; Novozhilov \& Golubeva 1986). The main reason might again be the relative acidity of dung in our study (4.6-7.3, mean $5.9 \pm 0.1)$. Presumably, all other conditions should be sufficient for myxomycete growth and development. The dung of the polar partridge was often encountered in dense shrub thickets, where the birds can find shelter. Besides Didymium difforme, Perichaena depressa, and the apparently new species of Perichaena, no myxomycetes were found exclusively on this substratum.

Noteworthy are the three weathered specimens of Lamproderma sauteri collected from a steep, south-exposed hillslope. According to our experience, this is a species found in nivicolous situations. As such, these specimens would establish the northernmost known records of a nivicolous myxomycete. 


\section{Distribution patterns of myxomycetes in the vegetation subzones of the Taimyr Peninsula}

Results of moist chamber cultures obtained for all substratum types in the different vegetation subzones are presented in Table 2. Due to the patchy nature of the vegetation, collections from one geographical locality may be assigned to more than one subzone. In general, the species richness of myxomycetes decreases northwards. The Shannon diversity index for the taiga $\left(\mathrm{H}^{\prime}=\right.$ 1.31 ) is slightly higher than the value for the forest-tundra $\left(\mathrm{H}^{\prime}=1.28\right)$, whereas the value for the tundra is much lower $\left(H^{\prime}=0.99\right)$. However, this pattern differs among particular ecological groups. For example, the mean value of the number of wood-inhabiting species per moist chamber culture decreases from 3.54 in the taiga to 1.66 and 1.13 in the forest-tundra and tundra, respectively. This correlates with a decrease in species richness and diversity (Table 2). Corticolous myxomycetes exhibit similar patterns. In contrast, litter-inhabiting myxomycetes exhibit a higher diversity in forest-tundra $\left(\mathrm{H}^{\prime}=1.01\right)$ and tundra $\left(\mathrm{H}^{\prime}=0.90\right)$ than in the taiga $\left(\mathrm{H}^{\prime}=0.58\right)$. Myxomycetes cultured from dung in the taiga subzone occurred too sporadically to indicate any distribution trends.

In the tundra, myxomycetes are represented mainly by multizonal and even cosmopolitan species. Many boreal species are widely distributed within the northern taiga and can be found also in forest-tundra and tundra vegetation. As noted above, some multizonal species show high population density in the southern tundra. However, only Echinostelium minutum (2 collections), Didymium dubium (2), Craterium leucocephalum (1), Licea minima (1), and L. testudinacea (1) were recorded for typical tundra (localities 9, 10). In addition, Arcyria cinerea (2 collections) and Trichia munda (1) were recorded in areas with mountain tundra on the Putorana Plateau and also may occur in the typical lowland tundra of the Taimyr Peninsula. Presumably, differences among myxomycete assemblages in taiga, forest-tundra, and tundra are more the result of differences in the abundance of shared species than actual differences in species composition. Only one species (Licea belmontiana) was recorded mainly in the southern tundra zone ( 7 collections, $70 \%$ of all collections). When coefficient of community indices were used as a measure to compare vegetation subzones, values between 0.53 and 0.66 were calculated (Table 3).

Although myxomycetes were represented in the tundra by almost the same number of families and genera as in forest-taiga and taiga, species numbers in the tundra were much lower. (Table 3 ). Among myxomycete families, members of the Trichiaceae (represented by 88 collections, 17 species, and 6 genera) and Stemonitaceae (76 collections, 8 species, and 5 genera) were found

Table 3. Comparison of myxomycete assemblages in the vegetation subzones of the Taimyr Peninsula. Both the community coefficient value (upper right) and the number of species shared by the territories (lower left) are given. Field collections were omitted for this analysis.

\begin{tabular}{lccc}
\hline & Northern taiga & Forest tundra & Tundra \\
\hline Northern taiga & $* * *$ & 0.66 & 0.65 \\
Forest tundra & 22 & $* * *$ & 0.53 \\
Tundra & 17 & 15 & $* * *$ \\
& & 36 & 21 \\
Number of species & 32 & 15 & 15 \\
Number of genera & 14 & 7 & 7 \\
Number of families & 8 & 5.1 & 1.5 \\
Species per family & 4 & 2.4 & 1.4 \\
Species per genus & 2.3 & & \\
\hline
\end{tabular}

to be most abundant in the Taimyr Peninsula. Both families contain many species able to endure a low substratum $\mathrm{pH}$. This trend was observed also in other areas of the arctic and the subarctic regions (Novozhilov et al. 1998b). In general, the species per genus (S/R) ratio, ranging from 1.4 to 2.4 within the three vegetation zones, is low compared with values obtained for temperate or tropical regions, where the $\mathrm{S} / \mathrm{R}$ ratio, ranges from 2.2 to 4.6 (Novozhilov 1985; Stephenson et al. 1993).

As shown in Table 4, the myxomycete biota of the Taimyr Peninsula is similar to those reported for other arctic and subarctic regions. Expressed as coefficient of community (CC) index, Russian northern Karelia has the most similar myxomycete biota $(\mathrm{CC}=0.51)$. Values for the northern taiga (Finland, Russian Karelia) range from 0.35 to 0.51 , whereas the data sets for temperate, tropical, mediterranean, and desert vegetation range from 0.20 to 0.36 . As might be expected, $\mathrm{CC}$ values for the desert zone reveal the least degree of similarity (0.20). Even when comparing our results with 
the data set from the most similar vegetation zone (Russian Karelia), the CC value is surprisingly low. An obvious reason is that many species not appearing in moist chambers are underrepresented in the present survey.

On the other hand, in comparison to surveys from the northern taiga that included results from many moist chamber cultures (Finland, Russian Karelia), the number of species recorded only in the present study was surprisingly high. Although most of these species are rare, our data point towards a certain degree of distinctiveness for the Taimyr myxomycete biota. On the other hand, it must be stated that many species (e.g., Echinostelium minutum, Comatricha nigra, and Arcyria cinerea as the three most abundant species) commonly recorded from the Taimyr Penin-

Table 4. Comparisons of the results of the present study with various regional myxomycete biotas from different climate zones. Note: CC - coefficient of community value; $\mathrm{T}$ - the total number of registered species recorded for the region; $\mathrm{S}$ - species recorded only in the Taimyr Peninsula; and $\mathrm{C}$ - the number of species shared in common.

\begin{tabular}{llrll}
\hline Regions & CC & T & S & C \\
\hline RK & 0.51 & 92 & 18 & 37 \\
Am1 & 0.36 & 56 & 37 & 18 \\
FL & 0.35 & 171 & 15 & 40 \\
TR & 0.35 & 41 & 38 & 17 \\
Am2 & 0.33 & 113 & 27 & 28 \\
ISR & 0.33 & 86 & 32 & 23 \\
CR & 0.31 & 108 & 30 & 25 \\
SI & 0.26 & 101 & 35 & 20 \\
PR & 0.24 & 79 & 39 & 16 \\
Da & 0.20 & 64 & 43 & 12 \\
\hline
\end{tabular}

Notes. Boreal zone, coniferous forest (taiga): Russian northern Karelia (RK) - (Schnittler \& Novozhilov 1996); Finland (FL) - (Härkönen 1978, 1979a, b, 1981a, b, 1989). Temperate zone: two areas of the northeastern United States: Cheat Mountain, coniferous forest (Am1), and Mountain Lake, mainly deciduous forest (Am2) - (Stephenson et al. 1993). Tropical zone: Southern India (SI) - (Stephenson et al. 1993); Costa Rica (CR) - (Alexopoulos \& Saenz 1975; Schnittler, pers. comm.); Puerto Rico (PR) - (Farr 1976; Hagelstein 1927, 1944; Martin \& Alexopoulos 1969; Novozhilov \& Rollins, pers. comm.). Mediteranean zone: Israel (ISR) - (Binyamini 1986, 1987, 1991; Lado 1994; Ramon 1968); Turkey (TR) - (Härkönen 1988, Härkönen \& Uotila 1983). Desert areas (Da): Arizona (Evenson 1961, Ranzoni 1968); Sonora desert (Blackwell \& Gilbertson 1980); Mongolia, Gobi desert (Novozhilov \& Golubeva 1986); Kazakhstan, Mangyshlak Peninsula (Schnittler, pers. comm.). sula are widely distributed throughout the world, having rather wide ecological amplitudes. Of the 56 species listed herein, only 28 were found more than twice (Table 1). At present, from surveys carried out in high-latitude regions of the northern hemisphere (the range of latitudes represented by the various study areas extends from $59^{\circ}$ to $77^{\circ} \mathrm{N}$ ), 150 myxomycete species from about 1800 collections are known (S.L. Stephenson, pers. comm.), compared with approximately 275 species from eastern north America (Martin \& Alexopoulos 1969) and 300 from India (Venkataramani \& Kalyanasundaram 1986).

\section{What are the distribution limits for myxomycetes in arctic regions?}

Obviously, the main factors for the decrease in the number of myxomycete species in arctic regions are unfavourable temperature conditions and the reduced range and extent of available microhabitats. Along with the surveys from Alaska (Stephenson \& Laursen 1993, 1998) and Greenland (Gøtzsche 1989), our survey is the northernmost one carried out thus far. With a high degree of continentality and extremely low winter temperatures, the climate of the Taimyr Peninsula is definitely very harsh, but the 56 myxomycete species recorded indicate that winter temperature is certainly not a limiting factor for myxomycete distribution.

A more important factor seems to be the mean July temperature. In the Taimyr Peninsula at $70^{\circ}$ $\mathrm{N}$, the mean July temperature usually varies between $10^{\circ}$ and $12{ }^{\circ} \mathrm{C}$ (Chernov \& Matveyeva 1997; Romanova 1971), which is a relatively high value for this latitude. In the southern tundra and the forest-tundra, daily air temperatures of $25^{\circ} \mathrm{C}$ can prevail for more than a week. Presumably, this is the reason why a species like Cribraria violacea with a mainly tropical distribution and a short development cycle can grow successfully, whereas numerous litter species of Didymium and Physarum (often common in temperate regions) with longer development times are seemingly absent.

For many cryptogams, fungi, insects or small animals, a lack of coarse woody debris is certainly a factor limiting their northern distribution (Samuelsson et al. 1994). In the present study, many myxomycetes were found also on tiny branchlets, although others with large fructifica- 
tions, such as Lycogala epidendrum, seem to be confined to larger logs. This may explain the only record of this species from Spitsbergen (Elvebakk et al. 1996), which was collected from the remnants of a wooden loghouse. Also, Enteridium splendens var. juranum was found exclusively on $\operatorname{logs}$ with a diameter $>20 \mathrm{~cm}$. In contrast, litter is available as a substratum even far north in typical tundra, and species of myxomycetes specialised for this substratum type may be more limited by macroclimate. In addition, the low levels of nutrients (especially nitrogen) in arctic soils may be a limiting factor, as possibly indicated by the virtual absence of the elsewhere common Didymium difforme, usually associated with nitrogen-rich substrata. In the north, this species may switch to dung. In Russian Karelia, it was found twice on litter and once on dung (Schnittler \& Novozhilov 1996), and in the Kola Peninsula (Novozhilov \& Schnittler 1997) once on dung.

The low $\mathrm{pH}$ values recorded for most substrata very probably constitute another limiting factor for myxomycete occurrence in the north, especially for many members of the Physarales, and certainly for bark-inhabiting species. All sampled substrata were rather acidic, especially bark (mean 4.2 $\pm 0.1,83$ samples measured), followed by wood ( $4.9 \pm 0.1,51$ samples), litter $(5.9 \pm 0.1,45$ samples), and dung (5.9 $\pm 0.1,25$ samples). In summary, there is a strong evidence that at least on the Taimyr Peninsula with its higher summer temperatures the northern limits of myxomycete distribution are much more determined by microhabitat availability than by macroclimatic conditions.

Acknowledgments. We acknowledge logistical support provided by Dr. D. Bolsheianov of the Arctic and Antarctic Research Institute, St. Petersburg, Russia. Appreciation is extended to Dr. I. Yu. Kirtsideli for collecting substratum samples for moist chambers in some areas of the Taimyr Peninsula. We also wish to express our thanks to L.A. Karzeva, St. Petersburg, for technical assistance during the SEM-investigations. We wish to thank D. Mitchell, United Kingdom, for his valuable comments relating to the collection of Licea belmontiana reported herein, Prof. J. Rammeloo (National Botanical Garden, Belgium), and Prof. U. H. Eliasson (Göteborg University, Sweden) for the loan of specimens of Licea belmontiana and $L$. denudescens. This work was supported in part by grants (N 96-04-48209, N 95-04-11790a, 98-07-90346) from the Russian Foundation for Basic Research [RFBR].

\section{References}

Alexandrova, V.D. 1977: The Arctic and Antarctic: their division into geobotanical areas [In Russian]. Nauka, Leningrad. 188 pp.

Alexopoulos, C.J. 1976: Absence of a capillitium as a taxonomic character in the myxomycetes. - Trans. Br. Mycol. Soc. 66: 329.

Alexopoulos, C.J. \& Saenz, J.A.R. 1975: The Myxomycetes of Costa Rica. - Mycotaxon 2: 223-271.

Binyamini, N. 1986: Myxomycetes from Israel - I. Nova Hedwigia 42: 379-386.

Binyamini, N. 1987: Myxomycetes from Israel - II. Nova Hedwigia 44: 351-364.

Binyamini, N. 1991: Myxomycetes from Israel - III. Trans. Mycol. Soc. Japan 32: 485-493.

Blackwell, M. \& Gilbertson, R.L. 1980: Sonoran Desert myxomycetes. - Mycotaxon 11: 139-149.

Chernov, Y.I. \& Matveyeva, N.V. 1997: Arctic ecosystems in Russia. - In: Wielgolaski, F.E. (ed.), Ecosystems of the World 3. Polar and Alpine tundra: 361507. Elsevier, Amsterdam \& Tokyo.

Chernusca, A. 1976: Bestandesstruktur, Bioklima und Energiehaushalt von alpinen Zwergstrauchbeständen. - Oecol. Plant. 11: 71-102.

Cox, J.L. 1981: Notes on coprophilous Myxomycetes from the Western United States. - Mycologia 73: $741-747$.

Czerepanov, S.K. 1995: Vascular plants of Russia and adjacent states (the former USSR). - Cambridge Univ. Press. 516 pp.

Eliasson, U.H. 1977: Recent advances in the taxonomy of myxomycetes. - Bot. Notiser 130: 483-492.

Eliasson, U.H. \& Keller, H. 1999: Coprophilous myxomycetes: updated summary, key to species, and taxonomic observations on Trichia brunnea, Arcyria elaterensis, and Arcyria stipata. - Karstenia 39: 1-10.

Eliasson, U.H. \& Lundqvist, N. 1979: Fimicolous myxomycetes. - Bot. Notiser 132: 551-568.

Eliasson, U.H. \& Strid, A. 1976: Wood-inhabiting fungi of alder forests in north-central Scandinavia. 3. Myxomycetes. - Bot. Notiser 129: 267-272.

Elvebakk, A., Gjærum, B.H. \& Sivertsen, S. 1996: Part 4. Fungi II. Myxomycota, Oomycota, Chytridiomycota, Zygomycota, Ascomycota, Deuteromycota, Basidiomycota: Uredinales and Ustilaginales. - In: Elvebakk, A. \& Prestrud P. (eds.), A catalogue of Svalbard plants, fungi, algae and cyanobacteria: $207-$ 259. Norsk Polarinstitutt, Oslo.

Evenson, A.E. 1961: A preliminary report of the myxomycetes of southern Arizona. - Mycologia 53: $137-144$.

Farr, M.L. 1976: Myxomycetes. - Flora Neotropica Monogr. 16: 1-304.

Fries, R.E. 1912: Den Svenska Myxomycet-Floran. Svensk Bot. Tidskr. 6: 721-802.

Gilert, E. 1990: On the identity of Perichaena liceoides (Myxomycetes). - Mycol. Res. 94: 698-704.

Gøtzsche, H.F. 1984: Contributions to the myxomycete flora of Iceland. - Acta Bot. Isl. 7: 13-26.

Gøtzsche, H.F. 1989: Myxomycetes from Greenland. Opera Bot. 100: 93-103.

Gøtzsche, H.F. 1990: Notes on Icelandic myxomycetes. - Acta Bot. Isl.10: 3-21. 
Hagelstein, R. 1927: Mycetozoa from Porto Rico. Mycologia 19: 35-37.

Hagelstein, R. 1944: The Mycetozoa of North America. - Publ. by the author. Mineola, New York. 306 pp.

Härkönen, M. 1977: Corticolous Myxomycetes in three different habitats in southern Finland. - Karstenia 17: 19-32.

Härkönen, M. 1978: On corticolous Myxomycetes in northern Finland and Norway. - Ann. Bot. Fennici 15: $32-37$.

Härkönen, M. 1979a: Additions and corrections to the Finnish flora of Myxomycetes. - Karstenia 19: 1-7.

Härkönen, M. 1979b: A check-list of Finnish Myxomycetes. - Karstenia 19: 8-18.

Härkönen, M. 1981a: Myxomycetes developed on litter of common Finnish trees in moist chamber cultures. Nordic J. Bot. 1: 791-794.

Härkönen, M. 1981b: Ten myxomycete species new to Finland. - Karstenia 21: 53-56.

Härkönen, M. 1988: Some additions to the knowledge of Turkish Myxomycetes. - Karstenia 27: 1-7.

Härkönen, M. 1989: Thirteen taxa of myxomycetes new to Finnland. - Karstenia 28: 93-99.

Härkönen, M. \& Koponen, M. 1978: Myxomycetes developed on grain in moist chamber cultures. Karstenia 18: 58-62.

Härkönen, M. \& Uotila, P. 1983: Turkish Myxomycetes developed in moist chamber cultures. - Karstenia 23: $1-9$.

Ing, B. 1994: The phytosociology of myxomycetes. The New Phytologist 126: 175-202.

Jahn, E. 1918: Myxomycetenstudien. 9. Bemerkungen über einige seltene oder neue Arten. - Ber. Dtsch. Bot. Ges. 36: 660-669.

Johannesen, E. 1984: New and interesting Myxomycetes from Norway. - Nordic J. Bot. 4: 513-520.

Keller, H.W. \& Brooks, T.E. 1971: A new species of Perichaena on decayed leaves. - Mycologia 63: 657663.

Keller, H.W. \& Brooks, T.E. 1977: Corticolous Myxomycetes 7: Contribution toward a monograph of Licea, five new species. - Mycologia 69: 667-684.

Keller, H.W. \& Eliasson, U.H. 1992: Taxonomic evaluation of Perichaena depressa and P. quadrata based on controlled cultivation, with additional observations on the genus. - Mycol. Res. 96: 1085-1097.

Kozhevnikov, Y.P. 1996: The vegetation cover of northern Asia in a historical perspective [In Russian, summary in English]. -. World and Family -95 Ltd., St. Petersburg. 400 pp.

Lado, C. 1994: A checklist of myxomycetes of the Mediterranean countries. - Mycotaxon 70: 117-185.

Martin, G.W. \& Alexopoulos, C.J. 1969: The Myxomycetes. - Univ. Iowa Press, Iowa City. 561 pp.

Novozhilov, Y.K. 1985: Conspectus Myxomycetum in URSS vigentium. - Novosti Sistematiki Nizhikh Rastenii [In Russian]. 22: 137-143.

Novozhilov, Y.K. 1986: De Myxomycetis Paeninsulae Czukotka notula. I. - Novosti Sistematiki Nizhikh Rastenii [In Russian]. 23: 143-146.

Novozhilov, Y.K. \& Golubeva, O.G. 1986: Epiphytic myxomycetes from the Mongolian Altai and the Gobi desert [In Russian]. - Mikologija i fitopatologija 20: $368-374$.
Novozhilov, Y.K. \& Schnittler, M. 1996: Myxomycetes of the Taimyr Peninsula - preliminary report. - Proceedings of third Workshop on Russian-German cooperation: Laptev Sea System: 20-21. Selbstverlag der Alfred-Wegener-Stiftung. Köln.

Novozhilov, Y.K. \& Schnittler, M. 1997: Nivicole Myxomycetes of the Khibine Mountains (Kola Peninsula). - Nordic J. Bot. 16: 549-561.

Novozhilov, Y.K., Schnittler, M. \& Stephenson, S.L. 1998a: The myxomycetes of Russian subarctic and arctic areas. - Mikologija i fitopatologija 32: 18-29.

Novozhilov, Y.K., Schnittler, M. \& Stephenson, S.L. 1998b: Analysis of myxomycete diversity of Russian subarctic and arctic areas. - Mikologija i fitopatologija 32: 27-33.

Petersen, J.H. 1996: The Danish Mycological Society's Colour-chart. - Foreningen til Svampekundskabens Fremme, Greve.

Rammeloo, J. 1974: Structure of the epispore in the Trichiaceae (Trichiales, Myxomycetes). As seen with the scanning electron microscope. - Bull. Soc. Roy. Bot. Belg. 107: 353-359.

Ramon, E. 1968: Myxomycetes of Israel. - Israel J. Bot. 17: 207-211.

Ranzoni, F.V. 1968: Fungi isolated in culture from soils of the Sonoran desert. - Mycologia 60: 356-370.

Roberts, D. W. 1986: Ordination on the basis of fuzzy set theory. - Vegetatio 66: 123-31.

Romanova, E.N. 1971: Microclimate of tundras near the Taimyr Biogeocenological Station [In Russian]. In: Tikhomirov B.N. (ed.), Biogeocenoses of Taimyr tundra and their productivity: 35-44. Nauka, Leningrad.

Samuelsson, J., Gustafsson, L. \& Ingelög, T. 1994: Dying and dead trees. - Swedish Environmental Protection Agency, Uppsala. 106 pp.

Schinner, F. 1983: Myxomycetes aus dem Gebiet des Torne Trósk (Abisko) in Schwedisch Lappland. Sydowia 36: 269-276.

Schnittler, M. \& Novozhilov, Y.K. 1996: The myxomycetes of boreal woodlands in Russian northern Karelia: a preliminary report. - Karstenia 36: 19-40.

Shannon, C.E. \& Weaver, W. 1963: The mathematical theory of communication. - Univ. Illinois Press, Urbana. $117 \mathrm{pp}$.

Sirois, L. 1983: The transition between boreal forest and tundra. - In: Shugart, H.H., Leemans, R. \& Bonan, G.B. (eds.), A system analysis of the global boreal forest: 196-215. Cambridge Univ. Press, New-York Sydney.

Stephenson, S.L. 1985: Slime molds in the laboratory II: Moist chamber cultures. - Amer. Biol. Teacher 47: 487-489.

Stephenson, S.L. 1988: Distribution and ecology of Myxomycetes in temperate forests I. Patterns of occurrence in the upland forests of south-western Virginia. - Canad. J. Bot. 66: 2187-2207.

Stephenson, S.L. 1989: Distribution and ecology of Myxomycetes in temperate forests. II. Patterns of occurrence on bark surface of living trees, leaf litter, and dung. - Mycologia 81: 608-621.

Stephenson, S.L., Kalyanasundaram, I. \& Lakhanpal, T.N. 1993: A comparative biogeographical study of myxomycetes in the mid-Appalachians of eastern 
North America and two regions of India. - J. Biogeogr. 20: 645-657.

Stephenson, S.L. \& Laursen, G.A. 1990: Distribution and ecology of myxomycetes in arctic and alpine ecosystems of western North America. - A. Reisinger \& A. Bresinsky (eds.), Proc. IV Intern. Mycol. Congress. Abstract IIC-1 68/3, Regensburg.

Stephenson, S.L. \& Laursen, G.A. 1993: A preliminary report on the distribution and ecology of Myxomycetes in Alaskan tundra. - Arctic and alpine Mycology 150: 251-257.

Stephenson, S.L. \& Laursen, G.A. 1998: Myxomycetes from Alaska. - Nova Hedwigia 66 (3/4): 425-434.

Stephenson, S.L., Novozhilov, Y.K. \& Laursen, G.A. 1994: A preliminary report of myxomycetes from boreal forest and arctic tundra ecosystems of central
Alaska and eastern Russia. - Proceedings of the West Virginia Academy of Science 66: 18.

Tikhomirov, B.A. 1970: Forest limits as the most important biogeographical boundary in the North. - In: Ecology of the subarctic regions. Proceedings of the Helsinki symposium: 35-40, UNESCO, Paris.

Tolmachev, A.I. 1960: Arctic flora of USSR [In Russian]. - Acad. Sci., Moscow - Leningrad. 101 pp.

Ukkola, T., Härkönen, M. \& Saarimäki, T. 1996: Tanzanian Myxomycetes: second survey. - Karstenia 36: 51-77.

Venkataramani, R. \& Kalyanasundaram, I. 1986: Distribution and ecology of Myxomycetes in India. - Proc. Indian Acad. Sci. (Plant Sci., Sect. B) 96: 289-301.

Whitney, K.D. 1980: The Myxomycete genus Echinostelium. - Mycologia 72: 950-987.

Received on 1 June 1999 